\title{
Aggregated aluminium exposure: risk assessment for the general population
}

\author{
Thomas Tietz $^{1}$ (1) A Ariane Lenzner ${ }^{1} \cdot$ Anna Elena Kolbaum $^{1} \cdot$ Sebastian Zellmer ${ }^{1} \cdot$ Christian Riebeling $^{1}$. \\ Rainer Gürtler ${ }^{1}$. Christian Jung ${ }^{1}$ - Oliver Kappenstein ${ }^{1}{ }^{10}$. Jutta Tentschert ${ }^{1} \cdot$ Michael Giulbudagian $^{1}$. \\ Stefan Merkel ${ }^{1} \cdot$ Ralph Pirow $^{1} \cdot$ Oliver Lindtner $^{1} \cdot$ Tewes Tralau $^{1}$ - Bernd Schäfer ${ }^{1} \cdot$ Peter Laux $^{1} \cdot$ Matthias Greiner $^{1}$. \\ Alfonso Lampen ${ }^{1} \cdot$ Andreas Luch $^{1} \cdot$ Reiner Wittkowski $^{1} \cdot$ Andreas Hensel $^{1}$
}

Received: 18 September 2019 / Accepted: 15 October 2019 / Published online: 28 October 2019

(c) The Author(s) 2019

\begin{abstract}
Aluminium is one of the most abundant elements in earth's crust and its manifold uses result in an exposure of the population from many sources. Developmental toxicity, effects on the urinary tract and neurotoxicity are known effects of aluminium and its compounds. Here, we assessed the health risks resulting from total consumer exposure towards aluminium and various aluminium compounds, including contributions from foodstuffs, food additives, food contact materials (FCM), and cosmetic products. For the estimation of aluminium contents in foodstuff, data from the German "Pilot-Total-Diet-Study" were used, which was conducted as part of the European TDS-Exposure project. These were combined with consumption data from the German National Consumption Survey II to yield aluminium exposure via food for adults. It was found that the average weekly aluminium exposure resulting from food intake amounts to approx. 50\% of the tolerable weekly intake (TWI) of $1 \mathrm{mg} / \mathrm{kg}$ body weight (bw)/week, derived by the European Food Safety Authority (EFSA). For children, data from the French "Infant Total Diet Study" and the "Second French Total Diet Study" were used to estimate aluminium exposure via food. As a result, the TWI can be exhausted or slightly exceeded—particularly for infants who are not exclusively breastfed and young children relying on specially adapted diets (e.g. soy-based, lactose free, hypoallergenic). When taking into account the overall aluminium exposure from foods, cosmetic products (cosmetics), pharmaceuticals and FCM from uncoated aluminium, a significant exceedance of the EFSA-derived TWI and even the PTWI of $2 \mathrm{mg} / \mathrm{kg} \mathrm{bw} / \mathrm{week}$, derived by the Joint FAO/WHO Expert Committee on Food Additives, may occur. Specifically, high exposure levels were found for adolescents aged 11-14 years. Although exposure data were collected with special regard to the German population, it is also representative for European and comparable to international consumers. From a toxicological point of view, regular exceedance of the lifetime tolerable aluminium intake (TWI/PTWI) is undesirable, since this results in an increased risk for health impairments. Consequently, recommendations on how to reduce overall aluminium exposure are given.
\end{abstract}

\section{Article Highlights}

- Risk assessment of total aluminium exposure from different sources for different age groups.

- Use of data from the European TDS-Exposure project for the estimation of aluminium exposure from foodstuff.

- Comprehensive overview of the toxicological properties of aluminium.

Keywords Aluminium · Dietary exposure $\cdot$ Cosmetics $\cdot$ Food contact materials $\cdot$ Risk assessment $\cdot$ Infants $\cdot$ Children . Adults · Toxicological overview

Thomas Tietz

Thomas.tietz@bfr.bund.de

1 German Federal Institute for Risk Assessment (BfR), Max-Dohrn-Strasse 8-10, 10589 Berlin, Germany

\section{Introduction}

After oxygen and silicon, aluminium is the third most abundant element and thus the most common metal of the earth's crust. Due to its properties, nowadays aluminium is used in 
numerous products and technical processes. Hence, it has become the second most important metallic material after steel. In 2017, approximately 64 million tons of aluminium were produced worldwide (IAI 2018). Considering the frequent discussion about the use of aluminium and its toxicological safety, the aim of this study was to estimate the overall exposure for consumers of different age groups and to perform a comprehensive risk assessment.

\section{Exposure}

Consumer exposure results from a variety of sources. Many unprocessed foods, such as fruits, vegetables, cereal products, and cocoa, inherently contain aluminium. In addition, there is a contribution from food additives and articles for packaging, processing or storage of foods, whether made of paper, plastic, ceramics or metal. Additional potentially significant sources of exposure are cosmetics and personal care products such as antiperspirants, toothpaste, and sunscreen, from which aluminium can be absorbed either orally or through the skin.

\section{Absorption distribution metabolism excretion (ADME)}

For the toxic effects of aluminium-apart from the skin irritation effect of some aluminium compounds-the systemically available amount is decisive. Aluminium compounds are usually poorly absorbed after oral ingestion (maximum about 1\%) (BfR 2014). Absorption varies by one to two orders of magnitude depending on the aluminium compound ingested and other parameters such as $\mathrm{pH}$ value, calcium or iron status as well as the amount ingested or presence of other substances. For instance, the uptake is increased by lactate, citrate, and fluoride and significantly reduced by the presence of silicates or phosphate. The average oral absorption from food is $0.1 \%$ (EFSA 2008). Absorption from drinking water is slightly higher with approximately $0.3 \%$ (SCHEER 2017). There are only a few studies on the dermal uptake of aluminium compounds, particularly in man. Uptake and urinary excretion were followed in an in vivo study on two individuals (one woman, one man), using the rare isotope ${ }^{26} \mathrm{Al}$. The isotope was applied to one armpit of each person in the form of aluminium chlorohydrate $(\mathrm{ACH})$ and the excretion was determined for 53 days. Based on their measurements and information on the mean renal excretion rate of $85 \%$ of the absorbed aluminium (Priest et al. 1995), the authors calculated an average absorption rate of $0.014 \%$ (Flarend et al. 2001). Recently published preliminary data from another, more comprehensive human toxicokinetics study (de Ligt et al. 2018) show very similar absorption rates through intact skin. An in vitro study (Pineau et al. 2012) showed average penetration rates through intact skin of
$1.6 \%, 0.6 \%$ and $2.0 \%$ for the formulations "deodorant spray", "roll-on" and "stick", respectively (calculated according to the "Notes of Guidance for the Testing of Cosmetic Ingredients and their Safety Evaluation" of the Scientific Committee on Consumer Safety of the European Commission (SCCS 2018) as the sum of the aluminium contents in living epidermis, dermis and receptor fluid). With $10.7 \%$, the penetration rate through skin samples in which the stratum corneum was damaged by "tape-stripping" was significantly higher (Pineau et al. 2012). The absorption of aluminium after uptake by inhalation is not sufficiently investigated to allow for a comprehensive exposure calculation (EFSA 2008). The existing studies estimate the absorption rate to $1.5-2 \%$, but cannot reliably prove whether aluminium absorption took place (only) via the lungs or (also) orally after mucociliary cleansing (Krewski et al. 2007; Yokel and McNamara 2001). Direct absorption via the nasal tract has also been discussed (Yokel and McNamara 2001).

After absorption, aluminium is distributed to all tissues. Accumulation takes place in almost all tissues, especially in bones and muscles, in the kidney, but also in the brain (COT 2013; EFSA 2008; JECFA 2012). The presence of aluminium in the lungs results primarily from aluminium compounds inhaled and deposited there.

Unabsorbed orally ingested aluminium is excreted via the faeces. In contrast, absorbed aluminium is excreted mainly via urine with a half-life of approximately 1 day in a first phase (JECFA 2012). After aluminium uptake over a longer period of time, the half-life increases to up to 50 years, which indicates the existence of various aluminium deposits in the body (EFSA 2008; JECFA 2012).

\section{Acute toxicity}

The acute toxicity of aluminium is low. The oral $\mathrm{LD}_{50}$ values for rats and mice are in the range of 162 and $980 \mathrm{mg}$ $\mathrm{Al} / \mathrm{kg}$ bw. The high variability is probably due to different systemically available concentrations of aluminium, since the absorption rate strongly depends on the respective aluminium compound used (EFSA 2008). Some aluminium compounds are irritating to skin. Irreversible toxic effects after dermal application, however, have not been described in the literature.

\section{Genotoxicity and carcinogenicity}

According to the current state of research, aluminium is neither genotoxic nor carcinogenic (COT 2013; EFSA 2008). Nevertheless, there is an ongoing debate about a possible (causal) relationship between the uptake of aluminium, specifically through the use of aluminium-containing antiperspirants, and the development of breast cancer (see BfR (2014) for details). Despite a number of studies in which the authors 
postulated a possible correlation (Darbre 2001; Exley et al. 2007; Mannello et al. 2011; Romanowicz-Makowska et al. 2012), up to now, aluminium could not be proven to be causative for cancer development. In animal studies even at high doses of up to $850 \mathrm{mg} / \mathrm{kg}$ bw/day, no carcinogenic effects were observed (Oneda et al. 1994), and also two epidemiological case studies failed to establish a connection between the use of antiperspirants and the incidence of breast cancer (Fakri et al. 2006; Mirick et al. 2002). After critical analysis of all published studies on the topic, a French expert group concluded in 2008 that the use of aluminium-containing antiperspirants is unlikely to be a risk factor for the development of breast cancer (Namer et al. 2008). Instead, other studies suggest that accumulation of aluminium in diseased tissue could be the result rather than the cause for cancer development (Mirick et al. 2002; Ogoshi et al. 1994). This hypothesis is further strengthened by the findings of other studies that the amount of other elements, such as iron, nickel, chromium and lead, is also significantly elevated in breast cancer tissue (Ionescu et al. 2007; Romaniuk et al. 2017). However, one recent study indicates the respective aluminium to at least partly originate from the use of antiperspirants (Lenhart et al. 2017).

\section{Reproductive toxicity}

Oral administration of aluminium in rabbits and dogs led to a decrease in testes weights and sperm quality. The highest no adverse effect levels (NOAELs) after oral ingestion in dogs were between 27 and $88 \mathrm{mg} / \mathrm{kg}$ bw/day (EFSA 2008). Detrimental effects on embryos were observed only at relatively high doses ( $\gg 100 \mathrm{mg} / \mathrm{kg}$ bw/day) (EFSA 2008; Pi et al. 2019).

\section{Neurotoxicity}

Since aluminium is able to cross the blood-brain barrier, it can reach and subsequently accumulate in the brain (BfR 2014; Inan-Eroglu and Ayaz 2018; Lukiw et al. 2019; Mehpara Farhat et al. 2019). At doses above $200 \mathrm{mg} / \mathrm{kg}$ bw/ day, neurotoxic effects such as behavioural disorders have been observed in animal experiments even in the absence of pathological lesions to the brain. Peripheral dysfunctions were also observed (Martinez et al. 2018). For disturbance of the vestibulo-ocular reflex in rats of different ages, EFSA determined a NOAEL of $30 \mathrm{mg} / \mathrm{kg}$ bw/day (EFSA 2008). In humans, elevated, toxicologically relevant levels of serum aluminium led to encephalopathy, as observed for example at high concentrations of aluminium in water parenterally administered to dialysis patients or as a consequence of therapeutic intake of aluminium hydroxide (Candy et al. 1992; Krewski et al. 2007; Seidowsky et al. 2018). In addition to brain damage, this so-called dialysis encephalopathy is also characterised by both anaemia and a vitamin D-resistant disorder of bone mineralisation (BfR 2007).

The German Permanent Senate Commission for the Investigation of Health Hazards of Chemical Compounds in the Work Area (MAK Commission) evaluated several studies on aluminium concentrations in the urine of human workers with respect to related cognitive deficiencies (Klotz et al. 2018). From these, the MAK Commission derived a NOAEL of $50 \mu \mathrm{g} \mathrm{Al} / \mathrm{g}$ creatinine. The "background concentration" (biological reference value; BAR value) in urine of not occupationally exposed humans was estimated to $15 \mu \mathrm{g} / \mathrm{g}$ creatinine (95th percentile) by the MAK Commission (Klotz et al. 2019).

In the past, neurotoxic effects of aluminium were frequently associated with Alzheimer's disease (AD) (InanEroglu and Ayaz 2018; Lukiw et al. 2019; Nie 2018), a disorder characterised by the accumulation of pathological amyloid deposits in the brain. These deposits are believed to originate from the conversion of membrane proteins as a result of the destruction of nerve cells or cell membranes, a phenomenon that increases with age. However, various epidemiological studies failed to connect aluminium levels in drinking water with the incidence of $\mathrm{AD}$, not the least due to inconsistencies within the available data. Also, for elevated levels of aluminium observed in damaged brain areas (Lukiw et al. 2019; Mold et al. 2019) of AD patients, it could not be elucidated whether the aluminium deposits were causative or rather symptomatic of the disease (for a detailed description, see BfR (2007)).

Furthermore, the neuropathological changes in AD significantly differ from those in patients suffering from dialysis encephalopathy. Therefore, a causal relation between aluminium and AD remains questionable (BfR 2007; EFSA 2008; IPCS 1997; JECFA 2012).

\section{Developmental toxicity}

For derivation of a tolerable weekly intake (TWI), EFSA (2008) considered developmental toxicity as the most critical endpoint. In a number of studies, both young and adult animals exhibited slowed reflexes, motor disturbances (grip strength), behavioural changes such as altered escape behaviour, as well as delayed puberty and adulthood. In some cases, learning and memory disorders could also be seen (Golub and Germann 2001). For the effects described, the lowest observed adverse effect levels (LOAELs) were in the range of $50-500 \mathrm{mg} / \mathrm{kg}$ bw/day. The lowest LOAEL and NOAEL of $50 \mathrm{mg} / \mathrm{kg}$ bw/day and $10 \mathrm{mg} / \mathrm{kg}$ bw/day, respectively, were used by EFSA (2008) as starting values for the derivation of a TWI. 


\section{Organ toxicity}

While EFSA chose developmental toxicity for the derivation of a TWI, JECFA (2012) considered the formation of concrements in the efferent urinary tract and the subsequent occurrence of hydronephrosis, which had been reported in a more recent 12-month study on rat developmental neurotoxicity (Poirier et al. 2011), as the most critical endpoints. The NOAEL was $30 \mathrm{mg} / \mathrm{kg}$ bw/day.

\section{Other toxicity}

Apart from the toxic effects already described above, repeated and long-term administration of aluminium in animal experiments was reported to also lead to unspecific effects such as reduced body weight gain, slight behavioural changes (e.g. anxiety or libido), as well as visual changes such as hair loss or piloerection (EFSA 2008; JECFA 2012; SCCS 2014). Toxicity to bone was reported in humans and animals (Klein 2019; Rodriguez and Mandalunis 2018).

To lower the overall exposure of consumers towards aluminium, the use or release, respectively, of aluminium is subject to regulation by various laws: Regulation (EU) No 10/2011 sets a Specific Migration Limit (SML) for the transition of aluminium from plastic materials into food (simulants) of $1 \mathrm{mg} / \mathrm{kg}$ food (simulant). In 2013, in consensus with the industry, the Council of Europe concluded that a maximum release of $5 \mathrm{mg}$ aluminium $/ \mathrm{kg}$ food from metals and alloys is technically achievable and sets this value as Specific Release Limit (SRL) (EDQM 2013). Regulation (EC) No 1333/2008 sets Maximum Levels (SMLs) for the use of various aluminium-containing food additives in certain foods. Furthermore, Regulation (EC) No 1223/2009 lays down restrictions such as maximum concentrations and conditions of use for the application of certain aluminium compounds in cosmetic products. The Directive on the safety of toys (Directive 2009/48/EC) sets migration limits for "dry, brittle, powder-like or pliable" $(5625 \mathrm{mg} / \mathrm{kg})$, "liquid or sticky" (1406 mg/kg), and "scraped-off" $(70,000 \mathrm{mg} / \mathrm{kg})$ toy materials, respectively.

Nevertheless, for consumers various sources of aluminium exposure are still present and risk assessment of the resulting overall exposure is necessary.

\section{Methods}

For the risk assessment, the estimated overall exposure was compared to the health-based guidance values derived by EFSA and JECFA for the age groups of infants and toddlers ( $\leq 36$ months), children (3-10 years), adolescents (11-14 years) and adults ( $>14$ years).

\section{Health-based guidance values}

To take account of the accumulation and very long half-life of aluminium in the body, instead of a tolerable daily intake (TDI) EFSA (2008) and JECFA (2012) derived a tolerable weekly intake (TWI) on the basis of the aforementioned adverse effects.

EFSA considers developmental neurotoxicity to be the most critical effect. The LOAELs from various studies are between 50 and $500 \mathrm{mg} / \mathrm{kg}$ bw/day, and the NOAELs range between 10 and $42 \mathrm{mg} / \mathrm{kg}$ bw/day (EFSA 2008). The lowest LOAEL/NOAEL originates from a study in mice (Golub and Germann 2001). EFSA included both the LOAEL of $50 \mathrm{mg} / \mathrm{kg}$ bw/day and the NOAEL of $10 \mathrm{mg} / \mathrm{kg}$ bw/day in the derivation of the TWI. This resulted in a TWI of $1 \mathrm{mg} /$ $\mathrm{kg}$ bw/week (EFSA 2008).

Based on a study in rats (Poirier et al. 2011), JECFA considers the formation of concrements in the efferent urinary tract and the resulting damage to the kidney as the most critical endpoint. Applying the NOAEL of $30 \mathrm{mg} / \mathrm{kg}$ bw/day JECFA (2012) derived a provisional TWI (PTWI) of $2 \mathrm{mg} /$ $\mathrm{kg}$ bw/week. This assessment was shared by the Scientific Committee on Consumer Safety (SCCS 2014) and the Scientific Committee on Health, Environmental and Emerging Risks (SCHEER 2017).

\section{Exposure assessment}

The overall exposure is compared to health-based guidance values (see above). These were derived for the oral route. They correspond to a systemic exposure after absorption in the gastrointestinal tract. Hence, analogous to the procedure of the Norwegian "Scientific Committee for Food Safety" (VKM 2013), we decided to first convert the contributions from non-oral sources via the respective absorption rates into a systemic exposure and afterwards to calculate an oral exposure which would lead to the same systemic exposure (oral exposure equivalents).

Where necessary, the following default body weight values were applied: $60 \mathrm{~kg}$ for adults (according to Regulation (EU) 10/2011), $42 \mathrm{~kg}$ for adolescents aged 11-14 years, $22 \mathrm{~kg}$ for children aged 3-10 years, $12 \mathrm{~kg}$ for infants aged 1-3 years and $6 \mathrm{~kg}$ for infants up to 12 months [all values are the median according to EFSA (2012)].

Although exposure data were collected with special regard to the German population, it is also representative for European and comparable to international consumers, because respective data sources were also taken into account. 


\section{Dermal aluminium exposure}

The most important non-dietary intake source of aluminium is dermal exposure from cosmetics, especially antiperspirants, which, according to a previous exposure estimation (BfR 2014), may reach or even exceed the TWI derived by EFSA. Exposure estimation is difficult as for most products robust data on the absorption rate through skin are lacking. However, in order to still be able to make an estimate, we used the results of an in vivo study (Flarend et al. 2001) on the dermal absorption of aluminium from antiperspirants, in which an absorption rate through intact skin of $0.014 \%$ was calculated. For the recalculation into an oral exposure, the mean rate of $0.1 \%$ for the absorption of aluminium from food estimated by EFSA (2008) is used.

To estimate the quantities of daily usage and the exposed skin surface for each product, the standard values of the SCCS "Notes of Guidance for the Testing of Cosmetic Ingredients and their Safety Evaluation" (SCCS 2018) were used.

\section{Oral aluminium exposure}

Food is presumed to be the most important contributor to oral exposure (EFSA 2008). Data on food consumption in adolescents and adults were taken from the German consumption study "Nationale Verzehrsstudie II" (National Nutrition Survey II; NVS II) of the Max Rubner Institute (MRI). The estimation is based on the data from two independent non-consecutive 24-h recalls, from 13,926 German individuals aged 14-80 years (Krems et al. 2006; MRI 2008). The intake estimates were based on the individual body weights of the respondents.

Data on the aluminium content of foods were taken from the German pilot total diet study (TDS), which was carried out within the framework of the European "Total Diet Study Exposure" (TDS-Exposure) project (http://www.tds-expos ure.eu) according to the criteria laid down by EFSA/FAO/ WHO (2011) [already described in Kolbaum et al. (2019)]. The selection of foods for the TDS is based on the consumption data of the NVS II and is described in detail by Dofkova et al. (2016). The food list comprises 246 different composite samples (pools), with each pool consisting of 12 individual samples, and covers $94 \%$ of the total food consumption. Foods from the food groups "Food products for young population" and "Additives, flavours, baking and processing aids" were not included, as they are either not or not significantly consumed by the adult population. Grocery shopping took place between March 2014 and February 2015 in the Berlin area (Germany). Before analysis, the food was prepared following procedures recorded in the NVS II or using typical household recipes from the best-selling recipe books. After preparation, the subsamples were pooled and homogenised with inert materials such as stainless steel or titanium to avoid contamination of the samples. The samples were analysed in duplicate using ICP-MS ("inductively coupled plasma mass spectrometry") at the BfR and at a contract laboratory. Both laboratories are accredited according to DIN EN ISO/IEC 17025. Depending on the respective matrix and laboratory, the limit of quantification (LOQ) was between 0.0002 and $0.72 \mathrm{mg} / \mathrm{kg}$. The tap water from the TDS kitchen was analysed separately, and aluminium values were found to be in a low range of $<0.05 \mathrm{mg} / \mathrm{kg}$.

To estimate the long-term dietary intake of aluminium, the occurrence data from the pilot TDS were linked to the consumption data of the NVSII. The calculation was carried out using the web-based probabilistic Monte Carlo Risk Assessment software MCRA (Version 8.2 and 8.2.11, https://mcra.rivm.nl) and applying the "observed individual means" (OIM) model. Results are displayed in $\mathrm{mg} / \mathrm{kg}$ bw/ week for both the average (mean) and the high-intake consumers (95th percentile, P95), including the corresponding $95 \%$ confidence intervals (CIs). For contents below the respective limit of quantification $(<\mathrm{LOQ})$, two approaches were used: In the Lower Bound (LB) approach, all values below LOQ are set to zero, while in the Upper Bound (UB) approach all values below LOQ are set equal to LOQ. In this way, the range of the actual exposure is described.

The pilot TDS considered food and consumption only for adults. Therefore, data from the second French TDS (ANSES 2011) and the French infant (i)TDS (ANSES 2016; Sirot et al. 2018) were used for the estimation of the dietary aluminium intake of infants, toddlers and children. In terms of methodology, representativeness and topicality, these data are currently considered as the most appropriate data basis for assessment of risk for the German population.

The application of aluminium and certain aluminium compounds as food additives in certain foods is permitted in the European Union according to regulation (EC) No $1333 / 2008$. In recent years, the usage of food additives containing aluminium has been restricted significantly. EFSA (2018) recently re-evaluated substances E520, E521, E522, E523 and E541 and considered the exposure resulting from the use of these additives to be negligible and hence of no safety concern. However, it was recommended that the combined exposure to aluminium from all the aluminiumcontaining food additives should be assessed. In addition, it should be noted that background exposure to food additives is already taken into account in the available TDS data by sampling of industrially produced processed foods. Hence, no additional contribution from food additives was considered for the overall aluminium exposure.

To estimate the oral exposure to cosmetic products such as toothpaste and lipstick, the specifications of the SCCS guideline "Notes of Guidance for the Testing of Cosmetic Ingredients and their Safety Evaluation" (SCCS 2018) 
Table 1 Mean, minimum and maximum aluminium contents from the German pilot TDS aggregated according to FoodEX2 level 1 main groups (in $\mathrm{mg} / \mathrm{kg}$ fresh weight) (Kolbaum et al. 2019)

\begin{tabular}{|c|c|c|c|c|c|c|}
\hline \multirow{2}{*}{$\begin{array}{l}\text { FoodEx } 2 \text { level } 1 \\
\text { Main food group }\end{array}$} & \multirow[t]{2}{*}{$N$} & \multirow[t]{2}{*}{$\%<\mathrm{LOQ}$} & \multicolumn{2}{|l|}{ Mean } & \multirow[t]{2}{*}{ Min } & \multirow[t]{2}{*}{ Max } \\
\hline & & & LB & UB & & \\
\hline Alcoholic beverages & 4 & 25 & 0.5 & 0.5 & $<\mathrm{LOQ}$ & 0.9 \\
\hline Animal and vegetable fats and oils & 3 & 100 & 0.0 & 0.1 & $<\mathrm{LOQ}$ & $<$ LOQ \\
\hline Coffee, cocoa, tea and infusions & 8 & 38 & 5.2 & 5.2 & $<\mathrm{LOQ}$ & 35.7 \\
\hline Composite dishes & 31 & 0 & 1.4 & 1.4 & 0.1 & 6.8 \\
\hline Eggs and egg-products & 2 & 0 & 0.3 & 0.3 & 0.3 & 0.3 \\
\hline Fish and seafood & 19 & 32 & 2.5 & 2.5 & $<\mathrm{LOQ}$ & 38.6 \\
\hline Fruit and fruit products & 27 & 15 & 1.3 & 1.4 & $<$ LOQ & 16.7 \\
\hline Fruit- and vegetable juices and nectars & 6 & 0 & 1.0 & 1.0 & 0.1 & 2.6 \\
\hline Grains and grain-based products & 22 & 5 & 2.3 & 2.3 & $<$ LOQ & 14.3 \\
\hline Legumes, nuts, oil seeds and spices & 10 & 0 & 28.5 & 28.5 & 0.7 & 243.5 \\
\hline Meat and meat products & 26 & 8 & 1.0 & 1.0 & $<$ LOQ & 4.1 \\
\hline Milk and dairy products & 15 & 27 & 0.5 & 0.6 & $<$ LOQ & 2.5 \\
\hline $\begin{array}{l}\text { Products for non-standard diets, food imitates } \\
\text { and food supplements (here soy and soy } \\
\text { products) }\end{array}$ & 3 & 0 & 3.2 & 3.2 & 0.4 & 7.3 \\
\hline Seasoning, sauces and condiments & 17 & 0 & 1.8 & 1.8 & 0.1 & 5.8 \\
\hline Starchy roots or tubers and products thereof & 7 & 14 & 1.5 & 1.5 & $<$ LOQ & 4.7 \\
\hline $\begin{array}{l}\text { Sugar, confectionary and water-based sweet } \\
\text { desserts }\end{array}$ & 12 & 8 & 21.1 & 21.1 & $<$ LOQ & 116.4 \\
\hline Vegetables and vegetable products & 26 & 15 & 1.1 & 1.2 & $<$ LOQ & 8.0 \\
\hline Water and water-based beverages & 5 & 80 & 0.1 & 0.2 & $<\mathrm{LOQ}$ & 0.5 \\
\hline Sum/*mean & 243 & 14 & $4.1 *$ & $4.1^{*}$ & & \\
\hline
\end{tabular}

$L O Q$ limit of quantification, $L B$ lower bound, $N$ number of pools in the main food group, $U B$ upper bound with regard to the daily amount of use of the products were applied. Contributions from other sources of exposure, e.g. food contact materials or pharmaceuticals, were estimated according to respective evaluations in the literature (BfR 2017b; PEI 2015; Sander et al. 2018).

\section{Aluminium exposure by inhalation}

Apart from residential areas in the vicinity of intensive aluminium mining, no significant inhalation exposure, e.g. from ambient air or house dust, is to be expected for consumers (SCHEER 2017). For the application of antiperspirant aerosol sprays, it could be assumed that a part of the spray might be inhaled. However, in a study on monkeys (Finkelstein and Wulf 1974), only $0.25 \%$ of the applied portion of spray was inhaled, even though it was sprayed directly into the face. The portion that reached the lower respiratory tract was even lower $(0.02 \%)$. Estimation of the exposure by inhalation is not possible, because data on the absorption rate via the lungs are not sufficiently reliable (EFSA 2008). However, application of the existing data (Krewski et al. 2007; Yokel and McNamara 2001) for a rough estimation shows that the combined dermal and inhalative exposure resulting from the use of antiperspirant aerosol sprays is lower than the exposure from the use of antiperspirant roll-ons or creams. This is due to the lower aluminium content in sprays in comparison to roll-ons or creams (IKW 2016a, b, d) as well as the lower quantities of daily usage of sprays according to SCCS (2018). Hence, in the exposure estimation, application of roll-ons or creams (without inhalative exposure) is used as worst case assumption.

\section{Results}

\section{Estimation of exposure from different sources}

\section{Aluminium content in foods}

The main sources of dietary aluminium exposure are summarised in Tables 1 and 2 [according to Kolbaum et al. (2019)].

Table 1 shows food in main groups according to EFSA's FoodEx 2 classification (EFSA 2011). Table 2 gives an overview of the ten food pools with the highest aluminium content. Aluminium was detected in $86 \%$ of the 243 samples. Food groups with especially high aluminium contents are "legumes, nuts, oilseeds and spices" and "sugars, sweets and water-based sweet desserts", with an average aluminium content of $28.5 \mathrm{mg} / \mathrm{kg}$ and $21.1 \mathrm{mg} /$ 
Table 2 Aluminium content of the ten food pools with the highest aluminium content in the German pilot TDS ( $\mathrm{mg} / \mathrm{kg}$ fresh weight)

\begin{tabular}{ll}
\hline $\begin{array}{l}\text { TDS Pool } \\
\text { (corresponding FoodEx2 Food group) }\end{array}$ & $\begin{array}{l}\text { Aluminium } \\
\text { content in } \\
\mathrm{mg} / \mathrm{kg}\end{array}$ \\
\hline $\begin{array}{l}\text { Spices } \\
\text { (Legumes, nuts, oil seeds and spices) }\end{array}$ & 243.5 \\
$\begin{array}{l}\text { Bitter chocolate (incl. filled) } \\
\text { (Sugar, confectionary and water-based sweet des- }\end{array}$ & $116.4^{\mathrm{a}}$ \\
$\quad$ serts) & \\
Syrups \\
(Sugar, confectionary and water-based sweet des- \\
$\quad$ serts) \\
$\begin{array}{l}\text { Mussels } \\
\text { (Fish and seafood) }\end{array}$ \\
$\begin{array}{l}\text { Cocoa powder and beverage powder } \\
\text { (Coffee, cocoa, tea and infusions) }\end{array}$ \\
$\begin{array}{l}\text { Pralines } \\
\text { (Sugar, confectionary and water-based sweet des- } \\
\quad \text { serts) }\end{array}$ \\
$\begin{array}{l}\text { Oilseeds } \\
\text { (Legumes, nuts, oil seeds and spices) }\end{array}$ \\
$\begin{array}{l}\text { Dried vine fruits } \\
\text { (Fruit and fruit products) }\end{array}$ \\
$\begin{array}{l}\text { Muesli and similar } \\
\text { (Grains and grain-based products) }\end{array}$ \\
$\begin{array}{l}\text { Chocolate spreads } \\
\text { (Sugar, confectionary and water-based sweet des- }\end{array}$ \\
$\quad$ serts) \\
\hline
\end{tabular}

${ }^{\text {a }}$ Large deviation $(31.4 \mathrm{mg} / \mathrm{kg}$ and $201.3 \mathrm{mg} / \mathrm{kg})$ in the duplicate analysis

$\mathrm{kg}$, respectively. The high contents found in these food groups are mainly due to the pools "spices" or cocoa-containing products, such as "bitter chocolate" and "pralines" (Table 2). For all other food groups the concentrations range between 0.1 and $5.2 \mathrm{mg} / \mathrm{kg}$. No aluminium was detected in the group "animal and vegetable fats and oils".

\section{Dietary aluminium intake for the German adult population}

The mean aluminium intake for the adult population (14-80 years) in Germany ranges between $0.18 \mathrm{mg} / \mathrm{kg}$ bw (LB) and $0.21 \mathrm{mg} / \mathrm{kg}$ bw (UB) per week (Table 3). For highly exposed persons (P95), the weekly aluminium intake ranges between $0.42 \mathrm{mg} / \mathrm{kg}$ bw (LB) and $0.44 \mathrm{mg} / \mathrm{kg}$ bw (UB). There are no significant differences between age and gender groups. These intake values correspond to $18-21 \%$ (mean) and $42-44 \%$ (P95) of the EFSA-derived TWI of 1 $\mathrm{mg} \mathrm{Al} / \mathrm{kg} \mathrm{bw} /$ week.

With $11 \%$ of total aluminium intake, the main contribution results from instant tea beverages. Other relevant sources of exposure are mixed vegetable salads, tea beverages, bitter chocolate and multigrain bread (see Fig. 1). Other cocoa and chocolate products also contribute to the overall aluminium intake (not shown separately). Hence, the data presented here are in line with the results of a study on aluminium intake via cocoa and chocolate products, which was carried out in 2017 on the basis of data from the German food monitoring programme (BfR 2017a).

Due to the high consumption in combination with the LOQ, natural mineral water appears to be among the main contributors of aluminium intake in the UB approach. However, aluminium content was below the detection limit in the respective samples. In general, there is only a slight difference between the LB and UB approach with respect to the main intake sources. Contributors are diversely distributed over different food groups and cannot be assigned to a specific consumption pattern.

The estimated aluminium intake through food in the German adult population [0.18-0.21 mg/kg bw/week (mean); $0.42-0.44 \mathrm{mg} / \mathrm{kg}$ bw/week (P95)] is in good accordance with other European data. The aluminium intake of adults in France was estimated to be on average at $0.28 \mathrm{mg} / \mathrm{kg}$ bw/ week and at $0.49 \mathrm{mg} / \mathrm{kg}$ bw/week for high-intake consumers (ANSES 2011; Arnich et al. 2012). The slightly higher values result from the applied middle bound approach in combination with significantly higher LOQ. In a recent study for the Italian adult population, a mean intake of $4.1 \mathrm{mg} /$ day (corresponding to $0.48 \mathrm{mg} / \mathrm{kg} \mathrm{bw} /$ week; bw $=60 \mathrm{~kg}$ ) was estimated (Filippini et al. 2019). Data from EFSA (2008) as well as studies from non-European countries such as Australia and New Zealand (FSANZ 2011, 2014; MPI 2016), Hong Kong (CFS 2013) or China (Liang et al. 2019) show slightly or significantly higher aluminium intakes. However, due to older data (EFSA 2008) or differences in the eating
Table 3 Long-term aluminium intake through food for the German adult population (14-80 years) and resulting exhaustion of the TWI/PTWI; data taken from the NVSII and the German pilot TDS

\begin{tabular}{|c|c|c|c|c|c|c|}
\hline \multicolumn{5}{|c|}{ Aluminium intake in $\mathrm{mg} / \mathrm{kg}$ bw/week } & \multicolumn{2}{|c|}{$\begin{array}{l}\text { Exhaustion of the EFSA- } \\
\text { TWI/JECFA-PTWI }\end{array}$} \\
\hline & LB & CI & UB & $\mathrm{CI}$ & LB & UB \\
\hline Mean & 0.18 & $(0.177 ; 0.181)$ & 0.21 & $(0.203 ; 0.207)$ & $18 \% / 9 \%$ & $21 \% / 11 \%$ \\
\hline Median & 0.14 & $(0.138 ; 0.143)$ & 0.17 & $(0.166 ; 0.169)$ & $14 \% / 7 \%$ & $17 \% / 9 \%$ \\
\hline 95th percentile & 0.42 & $(0.404 ; 0.427)$ & 0.44 & $(0.428 ; 0.449)$ & $42 \% / 21 \%$ & $44 \% / 22 \%$ \\
\hline
\end{tabular}

$b w$ body weight, $C I 95 \%$ confidence interval, $L B$ Lower bound, $U B$ Upper bound, $(P) T W I$ (provisional) tolerable weekly intake 

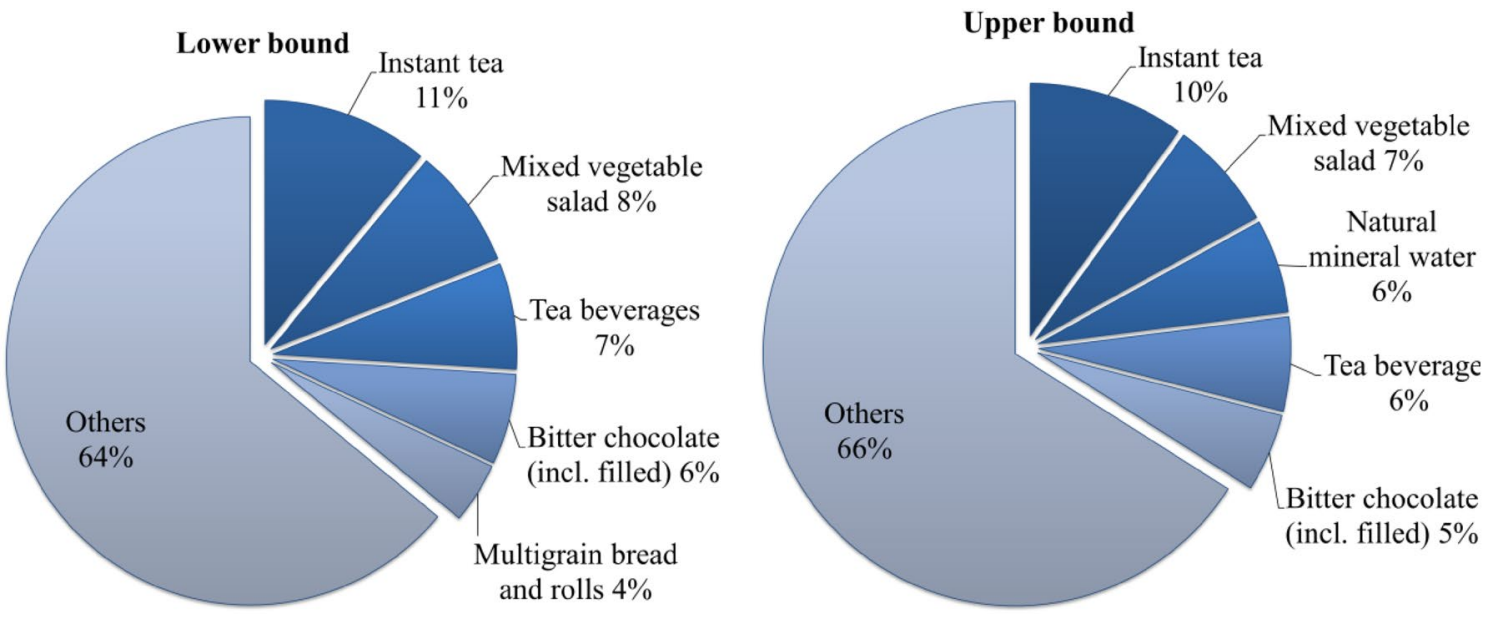

Fig. 1 Main contributors of dietary aluminium exposure in the German adult population (14-80 years) on the basis of NVSII and the German pilot TDS

Table 4 Long-term aluminium intake for infants and toddlers aged 1-36 months through food as estimated in the French 'Infant TDS' (iTDS) and resulting exhaustion of the TWI/PTWI (ANSES 2016; Sirot et al. 2018)

\begin{tabular}{|c|c|c|c|c|}
\hline \multirow[t]{2}{*}{ Age in months } & \multicolumn{2}{|l|}{ Mean } & \multicolumn{2}{|c|}{ 90th percentile } \\
\hline & LB & UB & $\mathrm{LB}$ & UB \\
\hline \multicolumn{5}{|c|}{ Aluminium intake in $\mathrm{mg} / \mathrm{kg}$ bw/week } \\
\hline $1-4$ & 0.21 & 0.22 & 0.43 & 0.43 \\
\hline $5-6$ & 0.32 & 0.32 & 0.52 & 0.52 \\
\hline $7-12$ & 0.35 & 0.36 & 0.55 & 0.56 \\
\hline $13-36$ & 0.37 & 0.39 & 0.61 & 0.62 \\
\hline \multicolumn{5}{|c|}{ Exhaustion of the EFSA-TWI/JECFA-PTWI } \\
\hline $1-4$ & $21 \% / 11 \%$ & $22 \% / 11 \%$ & $43 \% / 22 \%$ & $43 \% / 22 \%$ \\
\hline $5-6$ & $32 \% / 16 \%$ & $32 \% / 16 \%$ & $52 \% / 26 \%$ & $52 \% / 26 \%$ \\
\hline $7-12$ & $35 \% / 18 \%$ & $36 \% / 18 \%$ & $55 \% / 28 \%$ & $56 \% / 28 \%$ \\
\hline $13-36$ & $37 \% / 19 \%$ & $39 \% / 20 \%$ & $61 \% / 31 \%$ & $62 \% / 31 \%$ \\
\hline
\end{tabular}

bw body weight, $L B$ lower bound, $U B$ upper bound, $(P) T W I$ (provisional) tolerable weekly intake

habits or methods for exposure estimation, these data are not directly comparable to the data presented herein.

\section{Dietary aluminium intake for infants, toddlers and children}

The results from the French TDS and iTDS (ANSES 2011, 2016; Sirot et al. 2018), covering the age between $<1$ month and 14 years, are presented in Tables 4 and 5 . The mean aluminium intake increases from 0.21 to $0.37 \mathrm{mg} / \mathrm{kg}$ bw/week (LB) in the first 36 months. In the 90th percentile, the intake increases from 0.43 to $0.61 \mathrm{mg} / \mathrm{kg}$ bw/week (LB). According to the authors, the increase results from the stepwise inclusion of additional food products in the daily diet (Sirot et al.
Table 5 Long-term aluminium intake for children aged 3-14 years through food as estimated in the second French TDS (ANSES 2011) and resulting exhaustion of the TWI/PTWI

\begin{tabular}{llllll}
\hline Age in years & \multicolumn{2}{l}{$\begin{array}{l}\text { Aluminium intake in } \\
\mathrm{mg} / \mathrm{kg} \text { bw/week }\end{array}$} & & \multicolumn{2}{l}{$\begin{array}{l}\text { Exhaustion of the EFSA- } \\
\text { TWI/JECFA-PTWI }\end{array}$} \\
\cline { 2 - 3 } \cline { 5 - 6 } \cline { 5 - 6 } & Mean & 95th percentile & & Mean & 95th percentile \\
\hline $3-6$ & 0.64 & 1.02 & & $64 \% / 32 \%$ & $102 \% / 51 \%$ \\
$7-10$ & 0.49 & 0.82 & & $49 \% / 25 \%$ & $82 \% / 41 \%$ \\
$11-14$ & 0.34 & 0.58 & & $34 \% / 17 \%$ & $58 \% / 29 \%$ \\
\hline
\end{tabular}

$b w$ body weight, $(P) T W I$ (provisional) tolerable weekly intake ${ }^{a}$ Middle Bound approach

2018). Infant formula is the main source of aluminium intake until the 4th month (85\%). Afterwards, follow-on formulas, ready-to-eat vegetable meals for children, and vegetables (excluding potatoes) become increasingly important $(>10 \%)$ (Sirot et al. 2018). The resulting average dietary aluminium intake corresponds to $21-37 \%$ of the TWI derived by EFSA. High-intake consumers take up $43-61 \%$ of this TWI (Table 4).

Children aged 3-6 years have the highest dietary aluminium intake. Exposure for this age group is at $0.64 \mathrm{mg} / \mathrm{kg} \mathrm{bw} /$ week (mean) and $1.02 \mathrm{mg} / \mathrm{kg}$ bw/week (P95), corresponding to $64 \%$ and $102 \%$, respectively, of the TWI derived by EFSA (Table 5). With increasing age, aluminium intake gradually decreases to $0.34 \mathrm{mg} / \mathrm{kg}$ bw/week (mean) and $0.58 \mathrm{mg} /$ $\mathrm{kg}$ bw/week (P95). Vegetables (excluding potatoes), milkbased desserts and pasta are the main sources of aluminium intake among children (6-9\%).

The data from the second French TDI and the iTDS are in good accordance with another recent study on infants and 
Table 6 Aluminium content in breast milk

\begin{tabular}{lllll}
\hline Country & Year of sampling & Samples & Content & References \\
\hline Germany (Lower Saxony) & 2016 & 19 & $\begin{array}{l}\text { Mean: } 20 \mu \mathrm{g} / 1 \\
\text { Range: }<\text { LOD to } 40 \mu \mathrm{g} / 1\end{array}$ & LAVES (2017) \\
Taiwan & 2008 & 45 & $\begin{array}{l}\text { Mean: Colostrum: } 56 \pm 23^{\mathrm{a}} \mu \mathrm{g} / 1 \\
\text { Ripe milk: } 13 \pm 6^{\mathrm{a}} \mu \mathrm{g} / \mathrm{l}\end{array}$ & Chao et al. (2014) \\
Austria (Graz) & & 45 & $\begin{array}{l}\text { Median: } 67 \mu \mathrm{g} / 1 \\
\text { Range: }<10 \text { to } 380 \mu \mathrm{g} / 1\end{array}$ & Krachler et al. (2000) \\
Spain & n.s. & 27 & Mean: $23 \pm 10^{\mathrm{a}} \mu \mathrm{g} / \mathrm{l}$ & Fernandez-Lorenzo et al. (1999) \\
& n.s. & 45 & Range: 7 to $42 \mu \mathrm{g} / 1$ & Biego et al. (1998) \\
\hline
\end{tabular}

n.s. not specified, LOD limit of detection

${ }^{\text {a }}$ Standard deviation

toddlers conducted by the Austrian agency for health and food safety (AGES 2017).

The above-mentioned estimates for infants do not consider that alternatives for infant formulas (e.g. soy-based or hypoallergenic formula) may contain much higher aluminium contents. For example, Dabeka et al. (2011) found in an extensive study of 473 different infant formulas and substitutes in Canada on average about fourfold higher aluminium content in soy-based formulas ( $733 \mu \mathrm{g} / \mathrm{kg}$ ) compared to milk-based formulas $(177 \mu \mathrm{g} / \mathrm{kg})$. Other modifications, such as amino acid pattern adjustments, hypoallergenic or lactosefree milks, also show higher aluminium values. Chuchu et al. (2013) found in 20 products sampled in the UK on average 3.6-fold higher levels in soy-based infant formula $(706 \mu \mathrm{g} /$ $\mathrm{kg})(N=2)$ compared to the milk-based diet $(195 \mu \mathrm{g} / \mathrm{kg})$ $(N=18)$. All values refer to the conversion to reconstituted powder. Comparing data from the German TDS pilot with regard to aluminium contents in soy drinks $(1.8 \mathrm{mg} / \mathrm{kg})$ and cow milk (<LOQ) or soy yoghurt $(0.4 \mathrm{mg} / \mathrm{kg})$ and cow milk yoghurt $(<\mathrm{LOQ})$, respectively, indicates that the respective infant products in Germany may also contain higher aluminium contents if they are soy based.

EFSA (2008) also concluded that adapted infant formulas, such as soy-based or hypoallergenic products, result in significantly higher exposure. In contrast, the modelled aluminium intake for 3 months old, exclusively breastfed infants is with $0.04 \mathrm{mg} / \mathrm{kg}$ bw/week (average consumption) and $0.06 \mathrm{mg} \mathrm{Al} / \mathrm{kg}$ bw/week (high-intake consumption), respectively (EFSA 2008; JECFA 2007), much lower than the intake of children fed with adapted products or infant formula $(0.21-0.52 \mathrm{mg} / \mathrm{kg}$ bw/week in the first 6 months, compare Table 4). However, to model the data for breastfed infants, only one study from 1989 is used, which only reported contents below the limit of detection $(<50 \mu \mathrm{g} / \mathrm{l})$. Table 6 summarises more recent data on aluminium content in human milk. The results range from $100 \%$ below the limit of detection in France to a maximum of $380 \mu \mathrm{g} / \mathrm{l}$ milk for Austrian women. On average, values between 13 and $67 \mu \mathrm{g} / \mathrm{l}$ as well as high standard deviations are reported. Hence, the data used by EFSA and JECFA lead to a rational, though not especially conservative exposure estimation.

\section{Dietary aluminium intake summarised}

Figure 2 shows the cited French (ANSES 2011, 2016; Sirot et al. 2018) and the evaluated German data for the long-term dietary intake of aluminium in different age groups used for the risk assessment presented herein (data from Tables 3, 4,5 ). In the first months of life, aluminium intake increases steadily with increasing variability in food choices. It must be taken into account that only non-breastfed children were included. Aluminium intake via breast milk is significantly lower than via intake via infant food. From the age of 6 years on, the aluminium intake is decreasing. Adults have the lowest exposure in relation to their body weight. There is a large variation in aluminium intake from food, which could be attributed to variable background levels, use of food additives, food contact materials and eating habits. Hence, for brand loyal consumers of products with high aluminium contents and for consumers of adapted infant formula, higher aluminium intakes might result.

\section{Aluminium intake through food contact materials (FCM)}

Materials and articles which are used for production, packaging, cooking, eating and storage of food can release aluminium into the food. EFSA (2008) estimated the weekly aluminium exposure to be higher for elderly people living in care facilities due to the assumed more frequent consumption of food from aluminium menu trays (average consumers: 0.57 compared to $0.41 \mathrm{mg} \mathrm{Al} / \mathrm{kg}$ bw/week; high-intake consumers 1.14 compared to $0.88 \mathrm{mg} \mathrm{Al} / \mathrm{kg}$ bw/week). Significant transition of aluminium into food is to be expected above all when uncoated aluminium articles are used in connection with acidic, basic or salty foodstuffs. In this context, the BfR had reported high aluminium contents in lye biscuits 
Fig. 2 Long-term aluminium intake in different age groups. Data basis: French iTDS, second French TDS (ANSES 2011, 2016; Sirot et al. 2018) and German pilot TDS. Upper bound estimates for the age group 1-36 months and 14-80 years and middle bound estimates for the age group 3-6 years, respectively

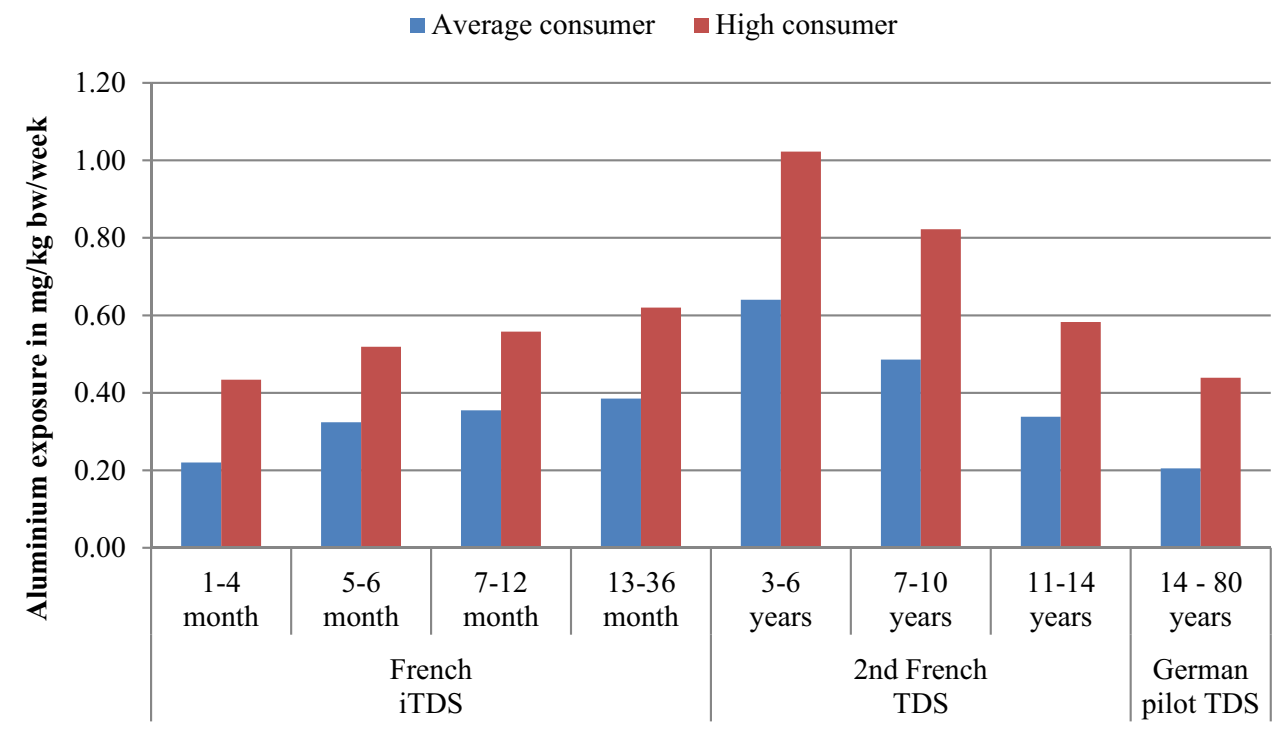

(BfR 2002) and apple juice (BfR 2008). In 2017, the BfR investigated menu trays made of uncoated aluminium for the release of this metal into acidic foods such as strained tomatoes, sauerkraut juice and apple puree during normal cooking and keeping warm procedures (cook \& chill), and calculated the additional contribution to the weekly exposure of an adult when eating a meal $(200 \mathrm{~g})$ per day at $0.5 \mathrm{mg} \mathrm{Al} /$ $\mathrm{kg}$ bw/week (BfR 2017b; Sander et al. 2018). Recent results support these findings (Ertl and Goessler 2018). Data on aluminium release from FCM made of ceramics (Beldì et al. 2016) or paper and board (BVL 2019) suggest that these FCM might be an additional source of aluminium exposure.

\section{Aluminium intake through lipsticks}

Lipsticks may contain colour pigments which contain aluminium or were produced by aluminium salt precipitation ("aluminium lakes"). Liu et al. (2013) analysed the aluminium content in 32 lipsticks. The maximum content was $27,000 \mathrm{mg} \mathrm{Al} / \mathrm{kg}$, the median $4431 \mathrm{mg} / \mathrm{kg}$. In 11 lipsticks/ lip gloss, the "Norwegian Institute for Air Research" determined aluminium contents of up to $28,000 \mathrm{mg} / \mathrm{kg}$ (NILU 2011). The median was $7700 \mathrm{mg} / \mathrm{kg}$. The Austrian AGES (2017) has examined 22 samples of lipsticks, incl. lip balm. The maximum content was $19,000 \mathrm{mg} / \mathrm{kg}$ and the mean at about $10,000 \mathrm{mg} / \mathrm{kg}$.

For lipsticks, only the oral route is relevant for the exposure assessment. Dermal uptake is expected to be negligible. For the calculation of the systemic exposure, the assumption that the whole amount applied to the lips is swallowed is considered to be conservative and covers a possible dermal exposure. According to the guideline of the SCCS (2018), about $0.057 \mathrm{~g}$ lipstick is applied daily. Based on the reported mean/median aluminium contents, the average weekly intake for an adolescent or adult ( $\mathrm{bw}=60 \mathrm{~kg}$ ) is 0.029-0.066 mg Al/kg bw/week (mean or median aluminium contents reported in the studies cited above were used for the calculation). However, application of the lipstick with the highest reported aluminium content of $28,000 \mathrm{mg} / \mathrm{kg}$ (NILU 2011) would result in an intake of $0.19 \mathrm{mg} \mathrm{Al} / \mathrm{kg}$ bw/week. For children between 11 and 14 years with a bw of $42 \mathrm{~kg}$ (see EFSA (2012)), the average exposure would be $0.042-0.073 \mathrm{mg} \mathrm{Al} / \mathrm{kg}$ bw/week, while the lipstick with the highest aluminium content would lead to a systemic exposure dose of $0.27 \mathrm{mg} \mathrm{Al} / \mathrm{kg}$ bw/week.

\section{Aluminium intake through toothpaste}

In toothpaste, the use of aluminium fluoride up to a concentration of $1500 \mathrm{ppm}(0.15 \%$ based on the fluoride content $)$ is permitted according to the European Cosmetics Regulation (Regulation (EC) No 1223/2009), but data on the actual use are scarce. However, the vast majority of products seem to contain sodium fluoride instead of aluminium fluoride. Hence, a relevant aluminium uptake can be expected only from the use of so-called "whitening" toothpastes, which may contain aluminium oxide or hydroxide as abrasives. According to a study by the predecessor institute of the Norwegian Food Safety Authority in 1997, the median value of the aluminium content is $4.5 \%$ (VKM 2013). Studies by AGES (2017) on 15 samples of toothpaste showed a high diversity of the results, with a mean content of $0.9 \%$ and a median of only $0.02 \%$. The highest content found was $3.9 \%$. According to SCCS (2018), about $2.75 \mathrm{~g}$ of toothpaste is used per day, of which about $138 \mathrm{mg}(5 \%)$ is swallowed. For an adult, an aluminium content of $0.02 \%$ AGES (2017) would lead to an exposure of $0.003 \mathrm{mg} \mathrm{Al} / \mathrm{kg}$ bw/week. For children between 11 and 14 years, the exposure would be 
$0.005 \mathrm{mg} \mathrm{Al} / \mathrm{kg}$ bw/week. In contrast, the content of $4.5 \%$ aluminium determined by the VKM (2013) would result in an oral exposure of $0.72 \mathrm{mg} \mathrm{Al} / \mathrm{kg}$ bw/week for adults and $1.0 \mathrm{mg} \mathrm{Al} / \mathrm{kg}$ bw/week for children.

\section{Dermal uptake of aluminium through antiperspirants}

In most cases, the active ingredient of antiperspirants is ACH (roll-ons and sprays). IKW (2016a, b, c, d) reports $\mathrm{ACH}$ concentrations of up to $30 \%$ for antiperspirant creams and pump sprays, corresponding to an aluminium content of approx. 7.5\%. AGES (2017) tested 25 antiperspirants and two deodorants for their aluminium content. As expected, the deodorant samples did not contain any aluminium. The antiperspirants contained between 0.2 and $5.8 \%$ aluminium, with an average content of $2.8 \%$. A study of the Bavarian State Office for Health and Food Safety (LGL 2018) on 69 samples resulted in aluminium contents between 0.2 and $5.7 \%$. The mean value for roll-on products was $2.9 \%$. According to SCCS (2018), approximately $1.5 \mathrm{~g}$ antiperspirant is used per day. For an average aluminium content of $2.8 \%$ (AGES 2017) this would result in an oral exposure equivalent of $0.69 \mathrm{mg} / \mathrm{kg}$ bw/week for adults and $0.98 \mathrm{mg} \mathrm{Al} / \mathrm{kg}$ bw/week for children between 11 and 14 years, respectively. For the antiperspirant with the highest measured aluminium content (5.8\%, AGES 2017), the exposure equivalent would even be $1.43 \mathrm{mg} \mathrm{Al} / \mathrm{kg}$ bw/week for adults and $2.04 \mathrm{mg} \mathrm{Al} / \mathrm{kg}$ bw/ week for children.

\section{Dermal uptake of aluminium through sunscreen}

Nicholson and Exley (2007) determined the aluminium content in several sunscreen products and reported the highest content to be above $0.1 \%$ (w/w). AGES (2017) examined 14 samples of sunscreens. The aluminium content in 5 samples was below the LOQ. The average content of the remaining samples was $0.1 \%$, with a maximum content of $0.8 \%$. According to SCCS (2018) and RIVM (2006), a daily application of $18 \mathrm{~g}$ of sunscreen is assumed on 25 days/year. For the average aluminium content of $0.1 \%$, an exposure equivalent of $0.02 \mathrm{mg} \mathrm{Al} / \mathrm{kg}$ bw/week would result for adults. For the sunscreen with the highest measured aluminium content (0.8\%), the exposure equivalent is $0.16 \mathrm{mg} \mathrm{Al} / \mathrm{kg}$ bw/week. According to SCCS (2018), the ratio of body surface area to body weight is not constant across all age groups. The ratio for 1-year, 5-year and 10-year-old children is 1.6, 1.5 and 1.3 times higher than the ratio for adults. Thus, maximum exposure equivalents for these age groups of $0.26,0.24$ and $0.21 \mathrm{mg} \mathrm{Al} / \mathrm{kg} \mathrm{bw} /$ week, respectively, are calculated.

\section{Other sources of exposure}

Aluminium is a necessary adjuvant in certain vaccines as well as a main component of certain drugs to neutralise gastric acid in heartburn or inflammation of the upper gastric tract (antacids). The "Paul Ehrlich Institute" (PEI) estimates that the cumulative intake of aluminium from all aluminiumcontaining vaccines recommended in Germany in the first 2 years of life (2-5.8 $\mathrm{mg}$ intramuscular) is in the range of the systemic exposure, which can be estimated from tolerable dietary intake based on European or WHO limits (TWI/ PTWI) for the same period (PEI 2015). Hence, an exposure equivalent of 1-2 $\mathrm{mg} \mathrm{Al} / \mathrm{kg}$ bw/week was calculated for children $\leq 2$ years.

Antacids may contain aluminium oxide or -hydroxide, -phosphate or aluminosilicates (RoteListe 2018). According to the "Model Lists of Essential Medicines" (WHO 2007), aluminium-containing antacids contain about $500 \mathrm{mg}$ of aluminium hydroxide in tablet form or $320 \mathrm{mg}$ (per $5 \mathrm{ml}$ ) in gel form. This would correspond to $173 \mathrm{mg}$ or $111 \mathrm{mg}$ aluminium per application. For an adult, this would correspond to an exposure of $1.85-2.88 \mathrm{mg} / \mathrm{kg}$ bw per application. Hence, for a day on which a person has to take the respective drugs, an uptake of up to $33 \mathrm{mg} \mathrm{Al} / \mathrm{kg}$ bw can result (Fischer 2014). This single intake would correspond to the sum of daily tolerable intakes over a period of more than 16 weeks, even if the higher PTWI-value derived by JECFA is used as a basis. However, the resorption rate in the gastrointestinal tract is significantly lower with a single administration of high doses of aluminium than with a continuous intake of low doses; aluminium from aluminosilicates is generally of very low bioavailability.

Other drugs contain aluminium, too, for example aluminium stearate as an excipient in tablet manufacture [up to 0.5-5\%, (Hunnius 2014)] or for antidiarrheal drugs. Another possible source of exposure for aluminium may be raw materials in cosmetic products containing water-insoluble aluminium compounds such as minerals, glass and clay/alumina, carbohydrate compounds or fatty acid salts. Insoluble minerals, glass and clay/alumina are added to cosmetic products as bulk ingredients, colour pigments and mild abrasives. However, there is not enough data to estimate the exposure from these sources.

There are also no representative quantitative data available on the aluminium content in toys. According to investigations by the German official control laboratories, which check compliance with the limits from Directive 2009/48/ EC (see above), none of the analysed samples (90 in total) exceeded these limits and, hence, toys have "harmless aluminium contents" (Lubecki 2014). However, migration from toys even below the current legal limit may contribute significantly to the overall aluminium exposure, especially for infants and toddlers. Currently, it is intended to lower 
Table 7 Total weekly aluminium exposure for infants and toddlers ( $\leq 36$ months), calculated as oral exposure equivalents

\begin{tabular}{|c|c|c|c|c|}
\hline \multirow[t]{2}{*}{ Exposure-contribution } & \multicolumn{4}{|c|}{ Weekly aluminium exposure in $\mathrm{mg} \mathrm{Al} / \mathrm{kg}$ bw/week } \\
\hline & $\begin{array}{l}\text { Breastfed } \\
\text { children (EFSA } \\
\text { 2008) }\end{array}$ & $\begin{array}{l}\text { 1-6 months (not breastfed) } \\
\text { (ANSES 2016; Sirot et al. } \\
\text { 2018) }\end{array}$ & $\begin{array}{l}\text { 7-24 months (ANSES } \\
\text { 2016; Sirot et al. 2018) }\end{array}$ & $\begin{array}{l}\text { 25-36 months (ANSES } \\
\text { 2016; Sirot et al. 2018) }\end{array}$ \\
\hline (1) Food, average consumers & 0.04 & $0.21-0.32$ & $0.35-0.39$ & $0.35-0.39$ \\
\hline (2) Sunscreens & $0.02-0.26$ & & & \\
\hline $\begin{array}{l}\text { Sum normally exposed persons without } \\
\text { vaccination }((1)+(2))\end{array}$ & $0.06-0.3$ & $0.2-0.6$ & $0.4-0.7$ & $0.4-0.7$ \\
\hline (3) Food, high-intake consumers & 0.06 & $0.43-0.52$ & $0.55-0.62$ & $0.55-0.62$ \\
\hline (4) FCM (containing aluminium) & - & 0.50 & 0.50 & 0.50 \\
\hline $\begin{array}{l}\text { Sum highly exposed persons without vac- } \\
\text { cination }((2)+(3)+(4))\end{array}$ & $0.08-0.3$ & $1.0-1.3$ & $1.1-1.4$ & 1.1-1.4 \\
\hline \multicolumn{5}{|l|}{ Other contributions } \\
\hline (5) Vaccines & $1-2$ & & & - \\
\hline $\begin{array}{l}\text { Sum normally exposed persons after } \\
\text { start of vaccination at } 2 \text { months } \\
((1)+(2)+(5))\end{array}$ & 1.1-2.3 & $1.2-2.6$ & 1.4-2.7 & - \\
\hline $\begin{array}{l}\text { Sum highly exposed persons after } \\
\text { start of vaccination at } 2 \text { months } \\
((2)+(3)+(4)+(5))\end{array}$ & $1.1-2.3$ & $2.0-3.3$ & 2.1-3.4 & - \\
\hline
\end{tabular}

Bold indicates the sum of the exposure estimation which is used for the risk assessment later on

the current migration limits in Directive 2009/48/EC by approx. 60\% (https://eur-lex.europa.eu/legal-content/EN/ TXT/?uri=pi_com:Ares(2019)89217), to adapt them to the current state of knowledge according to SCHEER (2017).

\section{Estimation of aggregated exposure for different age groups}

The relevant exposure contributions for different age groups are summed up below (Tables 7,8). To calculate exposure for "normally exposed individuals", the exposure to aluminium for normal food-consumers (mean or median, depending on the study) was used. Depending on the age group, additional contributions from sunscreens, lipsticks, toothpaste, antiperspirants and vaccines were considered. Additional contributions from the use of abrasive toothpaste and FCM were not taken into account. For the calculation of the exposure for "highly exposed individuals", the exposure values for high food-consumers (usually the 95th percentile) were used. In addition to the contributions for "normally exposed individuals", usage of aluminium-containing FCM and abrasive toothpaste was taken into account.

For infants, toddlers and children until 10 years of age, abrasive toothpaste, lipsticks and antiperspirants were not considered, because the use of these products in these age groups is expected to be very low. Vaccination was only considered as relevant source of exposure for infants and toddlers until the age of 24 months. For breastfed children, no additional intake from FCM was taken into account.
For infants, aluminium exposure is lowest if the children are breastfed (Table 7). Without consideration of vaccines, even for breastfed children with high consumption the maximum exposure is $0.3 \mathrm{mg} / \mathrm{kg}$ bw/week. After weaning, the exposure is significantly higher due to higher aluminium content in the diet as well as possible additional contributions from FCM. For highly exposed infants and toddlers, the maximum exposure is $1.4 \mathrm{mg} / \mathrm{kg}$ bw/week when vaccination is not considered.

For age groups other than infants and toddlers, the weekly aluminium exposure is lowest for children between 3 and 10 years (Table 8 ). This is due to the possible high impact of antiperspirants and abrasive toothpaste in the older age groups. If only the non-avoidable contributions from food and cosmetics are considered, the weekly aluminium exposure is significantly lower and does not differ much between the different age groups.

For not occupationally exposed adults, the MAK Commission estimated a 95th percentile of renal aluminium excretion of $15 \mu \mathrm{g} / \mathrm{g}$ creatinine (Klotz et al. 2019). A rough estimate of the daily aluminium intake (as oral exposure equivalents) can be calculated, if the following assumptions/ standard values are applied:

- Urinary aluminium concentrations in the studies resulted from continuous and relatively constant aluminium intake over a long time period.

- Between 80 and $90 \%$ of the absorbed aluminium is excreted via urine (Priest et al. 1995). 
Table 8 Total weekly aluminium exposure for children ( $>36$ months) and adults, calculated as oral exposure equivalents

\begin{tabular}{|c|c|c|c|}
\hline \multirow[t]{2}{*}{ Exposure-contribution } & \multicolumn{3}{|c|}{ Weekly aluminium exposure in $\mathrm{mg} \mathrm{Al} / \mathrm{kg}$ bw/week } \\
\hline & $\begin{array}{l}\text { Children 3-10 years, } \\
\text { data from ANSES } \\
\text { (2011) }\end{array}$ & $\begin{array}{l}\text { Children } 11-14 \text { years, } \\
\text { data from ANSES } \\
(2011)\end{array}$ & $\begin{array}{l}\text { Adults }>14 \text { years } \\
\text { data from this } \\
\text { work }\end{array}$ \\
\hline (1) Food, average consumers & $0.49-0.64$ & 0.34 & $0.18-0.21$ \\
\hline (2) Toothpaste, mean Al-content (not abrasive) & 0.005 & 0.005 & 0.003 \\
\hline (3) Lipsticks & - & $0.042-0.27$ & $0.029-0.19$ \\
\hline (4) Sunscreens & $0.02-0.24$ & $0.02-0.21$ & $0.02-0.16$ \\
\hline (5) Antiperspirants & - & $0.98-2.04$ & $0.69-1.43$ \\
\hline Sum normally exposed persons (sum (1) - (5)) & $0.5-0.9$ & 1.4-2.9 & 0.9-2.0 \\
\hline Sum normally exposed persons without antiperspirants (sum (1) - (4)) & $0.5-0.9$ & $0.4-0.8$ & $0.2-0.6$ \\
\hline (6) Food, high-intake consumers & $0.82-1.02$ & 0.58 & $0.42-0.44$ \\
\hline (7) Abrasive toothpaste, high Al-content & - & 1.0 & 0.72 \\
\hline (8) FCM (containing aluminium) & 0.50 & 0.50 & 0.50 \\
\hline Sum highly exposed persons (sum $(2)-(5)+$ Sum $(6)-(8))$ & 1.3-1.8 & $3.1-4.6$ & 2.4-3.4 \\
\hline $\begin{array}{l}\text { Sum highly exposed persons without antiperspirants, abrasive toothpaste } \\
\text { and FCM (sum }(2)-(4)+(6))\end{array}$ & $0.8-1.3$ & $0.6-1.1$ & $0.5-0.8$ \\
\hline \multicolumn{4}{|l|}{ Other contributions } \\
\hline Antacids, containing aluminium & - & - & $\begin{array}{l}1.85-2.88 \mathrm{mg} / \mathrm{kg} \\
\text { bw per applica- } \\
\text { tion }\end{array}$ \\
\hline
\end{tabular}

Bold indicates the sum of the exposure estimation which is used for the risk assessment later on

- Creatinine excretion is between 15 and $25 \mathrm{mg} / \mathrm{kg}$ bw/day, or 0.9-1.5 g/day for an adult with a body weight of $60 \mathrm{~kg}$, respectively (Inker and Levey 2014).

- Mean oral absorption rate is $0.1 \%$ (EFSA 2008).

Applying these assumptions, the aluminium intake (as oral exposure equivalents) for highly exposed adults (95th percentile) is calculated to $1.8-3.3 \mathrm{mg} / \mathrm{kg}$ bw/week. Despite the rough assumptions, this value is in good accordance with the exposure estimation described above (Table 8).

\section{Discussion}

For risk characterisation, the respective weekly aluminium exposure for the different age groups is compared to the EFSA-derived TWI of $1 \mathrm{mg} / \mathrm{kg}$ bw/week (based on developmental neurotoxicity) and the JECFA-derived PTWI of $2 \mathrm{mg} / \mathrm{kg}$ bw/week (based on impairments of the urinary tract and kidney), respectively (Table 9).

\section{Risk assessment for infants and toddlers}

The EFSA-derived TWI is exhausted or in some cases significantly exceeded for infants and toddlers ( $\leq 36$ months), regardless of the type of diet (Table 9). The JECFA-derived PTWI can also be exhausted or exceeded in this population group (see also BfR (2012)).
A significant part of the exposure results from the vaccinations recommended by the WHO and the Robert Koch Institute (RKI 2017). However, these vaccinations have a high health benefit, both for the individual and for the population as a whole (RKI 2016). Moreover, they only provide a relevant contribution to aluminium exposure in the first 2 years of life and not the whole of life. Clinical and epidemiological studies also show that exposure to aluminium from vaccines does not pose a health risk (PEI 2015; RKI 2016; WHO 2012). However, the additional exposure of infants and young children to aluminium via food and FCM should be as low as possible. Exposure to aluminium in breast milk diets is significantly lower than in other diets (BfR 2012, Table 7). Particularly certain adapted diets (e.g. soy based, lactose free, hypoallergenic) lead to increased exposure. For non-breastfed highly exposed children, the calculation shown in Table 9 also includes an additional contribution from FCM made of uncoated aluminium. If such additional contributions are strictly reduced or avoided, the JECFA-derived PTWI is not or only slightly exceeded. However, an (partly significant) exceedance of the EFSA-derived TWI is possible particularly for high-intake consumers and children fed with certain adapted foods. This population group is thus subject to a potentially increased health risk which has to be seen critically, especially with regard to developmental neurotoxicity. 
Table 9 Summary of the aggregated exposure values (as oral exposure equivalents) for the different population groups and comparison with the oral tolerable weekly intake of $1 \mathrm{mg} \mathrm{Al} / \mathrm{kg}$ bw/week (EFSA 2008) and $2 \mathrm{mg} \mathrm{Al} / \mathrm{kg}$ bw/week (JECFA 2012); values printed in bold type refer to exhaustion or excess of the respective (P)TWI; "normal exposure" refers to average consumers and does not take into account additional (avoidable) inputs (e.g. antiperspirants, food contact materials), which were included in "high exposure" calculation (for details, see Tables 7, 8)

\begin{tabular}{|c|c|c|c|}
\hline Population/age group & $\begin{array}{l}\text { Weekly aluminium } \\
\text { exposure in } \mathrm{mg} \mathrm{Al} / \mathrm{kg} \\
\text { bw/week }\end{array}$ & $\begin{array}{l}\text { Percentage of the EFSA- } \\
\text { TWI of } 1 \mathrm{mg} / \mathrm{kg} \mathrm{KG} / \\
\text { week }\end{array}$ & $\begin{array}{l}\text { Percentage of the JECFA- } \\
\text { PTWI of } 2 \mathrm{mg} / \mathrm{kg} \mathrm{KG} / \text { week }\end{array}$ \\
\hline Infants, breastfed & $1.1-2.3$ & 110-230 & $55-115$ \\
\hline $\begin{array}{l}\text { Infants and toddlers (1-6 months), fed with infant formula, } \\
\text { normal exposure }\end{array}$ & $1.2-2.6$ & $120-260$ & 60-130 \\
\hline $\begin{array}{l}\text { Infants and toddlers (1-6 months), fed with infant formula, } \\
\text { high exposure }\end{array}$ & $2.0-3.3$ & 200-330 & 100-165 \\
\hline Infants and toddlers ( 7 months -3 years), normal exposure & $1.4-2.7$ & $140-270$ & 70-135 \\
\hline Infants and toddlers ( 7 months -3 years), high exposure & $2.1-3.4$ & 210-340 & $\mathbf{1 0 5}-\mathbf{1 7 0}$ \\
\hline Children (3-10 years), normal exposure & $0.5-0.9$ & $50-90$ & $25-45$ \\
\hline Children (3-10 years), high exposure & $1.3-1.8$ & 130-180 & $65-90$ \\
\hline Adolescents (11-14 years), normal exposure & $1.4-2.9$ & $140-290$ & 70-145 \\
\hline Adolescents (11-14 years), high exposure & $3.1-4.6$ & $310-460$ & $155-230$ \\
\hline Adults ( $>14$ years), normal exposure & $0.9-2.0$ & 90-200 & 45-100 \\
\hline Adults ( $>14$ years), high exposure & $2.4-3.4$ & 240-340 & 120-170 \\
\hline
\end{tabular}

\section{Risk assessment for children and adolescents}

For children between 3 and 10 years of age, summed aluminium exposure (Table 9) from the contributions considered here exceeds the EFSA-derived TWI only in the highly exposed group (details see Table 8). The JECFA-derived PTWI is not exceeded. For normally exposed children in this age group, weekly aluminium intake does not exceed the EFSA-derived TWI. An increased health risk is, therefore, unlikely.

A different picture emerges for 11 to 14 years old. For this population group, additional contributions from cosmetic articles have to be considered. The use of aluminium-containing antiperspirants and abrasive toothpaste with a high aluminium content results in a total aluminium exposure in the highly exposed group that is almost fivefold as high as the EFSA-derived TWI (or 2.5-fold as high as the JECFAderived PTWI). An increased health risk is possible on the basis of these values. Since aluminium also accumulates in the body and remains there for a very long time even after a reduction in intake, a high exposure of very young people must be viewed particularly critically.

However, if aluminium-containing antiperspirants, abrasive toothpaste and FCM made of uncoated aluminium are avoided, the weekly intake is reduced to a range of $0.4-0.8 \mathrm{mg} \mathrm{Al} / \mathrm{kg}$ bw/week for normally exposed individuals and $0.6-1.1 \mathrm{mg} \mathrm{Al} / \mathrm{kg}$ bw/week for highly exposed individuals (see Table 8). The JECFA-derived PTWI would thus not be exceeded and the EFSA-derived TWI would only be slightly exceeded in the high exposure group. An increased health risk would, therefore, be unlikely if the above-mentioned avoidable contributions were omitted consequently.

\section{Risk assessment for adults}

Similar to adolescents, the aluminium exposure for adults may, in some cases significantly, exceed the EFSA-derived TWI for normally exposed adults. In the highly exposed group, even the JECFA-derived PTWI may be exceeded by more than 50\% (Table 9) and, thus, an increased health risk is possible. Cosmetic products contribute to a large (and through avoidance controllable) extent to this overall exposure (details see Table 8). Aluminium can cross the placental barrier, and the unborn child could also be exposed to aluminium. Antacids that contain bioavailable aluminium or form it in reaction with gastric acid can be an additional contribution to the overall aluminium exposure shown in Table 9. Meanwhile, the WHO has removed these antacids from its "Model List of Essential Medicines" (WHO 2017).

By consequent reduction or avoidance of additional contributions (e.g. cosmetics, FCM), the overall aluminium intake would be significantly lower than both the JECFAderived PTWI and the EFSA-derived TWI. Hence, an increased health risk would be unlikely.

\section{Uncertainty analysis}

\section{Uncertainties in the toxicological data}

There is no consensus regarding the derivation of a (P)TWI (see above). Depending on the (P)TWI used for comparison 
with the calculated exposure, different conclusions concerning a potential health risk may arise, because a particular exposure might at the same time exhaust or exceed the EFSA-derived TWI, but not the JECFA-derived PTWI.

Further research is needed concerning relevant toxicological endpoints, such as carcinogenicity and neurotoxicity of aluminium compounds. Nevertheless, up to now, there is no causal relationship between aluminium exposure and Alzheimer's disease or breast cancer development.

\section{Uncertainties in the data used for exposure assessment}

Aggregated exposure assessment based on several data sources as presented here naturally suffers from inherent uncertainties due to the different quality of the underlying data. Whereas the data on food exposure are based on comparatively large consumption and content data at individual level, the measured aluminium contents and data of use of cosmetics are based on assumptions or data sources that are not necessarily representative or do not cover the full variability. Thus, the contribution of each source to the total exposure might be affected by those uncertainties.

The dietary exposure assessment for adults is based on data from a pilot TDS. In consequence of the pilot character, uncertainties due to limited stratification regarding regional and seasonal variations in eating habits and the limited access to market share data arise. Nevertheless, the impact on the exposure outcome is considered as minor, since regional and seasonal variance is assumed to be low for environmental contaminants such as aluminium. In addition, standardised sampling strategies were applied to minimise the effect of missing market share data. Probably the highest amount of uncertainty, however, arises from a possible change of the consumption habits of consumers since $2005 / 2006$, when the consumption data collection period of the NVS II took place. For infants and children, more recent data from the French TDSs were used. Nevertheless, uncertainties may arise from different dietary behaviour of German infants and children, despite the similar culture space.

A TDS measures mean analyte contents of pooled samples. Hence, it is appropriate to estimate background exposure levels. High analyte contents of particular single foods cannot be detected. Therefore, individuals, who frequently consume certain highly contaminated products, such as brand loyal consumers, might be exposed to a much higher extent.

The considered data on aluminium release from FCM are limited to a small selection of products. A certain overestimation of the respective contribution to aluminium exposure might be possible, because the data are obtained under conservative conditions (food simulant, time, temperature). However, since this contribution was considered only for highly exposed individuals, the impact on the total intake should be small. The data on aluminium contents of cosmetic products are very limited, too. Both the extent and the direction (under- vs. overestimation) of the contribution to the total aluminium exposure are uncertain. The standard application amounts and frequencies for different cosmetic products according to SCCS (2018) are suitable for a conservative risk assessment (application of 90th percentile, each). Nevertheless, different application habits may occur. For example, recent data (Manová et al. 2013) indicate that the number of days on which sunscreen is used may be significantly higher than assumed here and that there is a variability in gender and age that is not sufficiently reflected by the standards used here.

Due to the lack of representative quantitative data on aluminium contents in toys, the contribution from this source is not considered in the assessment presented here.

\section{Methodological uncertainties}

Since for aluminium, systemic toxicity has been extensively studied only after oral intake, contributions from dermal exposure were converted into a systemic exposure based on the dermal absorption rate of $0.014 \%$, and afterwards recalculated into oral exposure equivalents that would result in the same systemic exposure, applying the oral absorption rate of $0.1 \%$. The dermal absorption rate is based on an in vivo study on antiperspirants (Flarend et al. 2001). For products other than antiperspirants leading to dermal aluminium exposure (e.g. sunscreen), it is unknown to what extent the use of the absorption rate of $0.014 \%$ can be justified, because these products usually contain matrix components or aluminium compounds different from those in antiperspirants (e.g. aluminium oxide or hydroxide instead of $\mathrm{ACH}$, as often used in antiperspirants) and are applied to other areas of the skin. In addition, dermal absorption rates observed in a recent in vitro study are many times higher (between 0.6 and $2.0 \%$ ) and suggest that aluminium is absorbed much better through damaged skin than through intact skin (Pineau et al. 2012). However, due to the somewhat artificial application mode as well as some uncertainties in the in vitro study, and in the absence of other data, the absorption rate of $0.014 \%$ from the in vivo study was used to calculate the systemic exposure after dermal absorption for all cosmetic products included here. However, it should be considered that higher aluminium levels might result from the use of aluminium-containing antiperspirants on damaged skin (e.g. after sunburn, shaving). Uncertainties may arise from the application of the oral absorption rate of $0.1 \%$, too, because this value only represents an average of the results reported in a large number of studies with highly differing absorption rates (see above). For example, the oral bioavailability of aluminium ingested via lipstick might be very low due to the use of insoluble colour pigments and it is not 
known whether the aluminium oxide or hydroxide used as an abrasive in toothpaste is bioavailable to the same extent as aluminium compounds ingested with food.

The aggregated analysis of the different exposure contributions carried out here allows the comparison of the significance of the individual pathways and the provision of options for risk management. However, data on correlations between different exposure contributions are missing. Therefore, uncertainties arise from the aggregated consideration of different contributions. A probabilistic assessment might be more appropriate, but would require sound assumptions on correlations or data on consumer behaviour considering all exposure contributions based on the same study population. With this, evaluation of variability and a more accurate exposure assessment on high percentiles would be possible. Additionally, human biomonitoring data could provide a valid basis for the actual internal exposure resulting from aggregated external exposure. The 95th percentile of the urinary aluminium concentration of not occupationally exposed adults, estimated by the MAK Commission (Klotz et al. 2019), corresponds to an oral exposure equivalent, which is in good accordance with exposure estimation presented here. However, these data are less appropriate to derive specific risk management measures.

\section{Conclusions}

More recent data (see results) indicate a significant reduction in aluminium intake from food compared to older data resulting in only a slight exceedance of the weekly tolerable aluminium intake (TWI) of $1 \mathrm{mg} \mathrm{Al} / \mathrm{kg}$ bw/week derived by the EFSA (2008) for high-intake consumers aged 3-6 years. For all other age groups, even high food consumption does not result in an exceedance of the TWI. The highest average exposure (3-6 years old children) is $64 \%$ of the TWI. Hence, no health risk due to dietary uptake alone is to be expected.

However, additional sources of exposure, such as the use of FCM made of uncoated aluminium, or the frequent use of aluminium-containing cosmetic products, could result in a permanent exceedance of the (P)TWI for a very large number of consumers in all age groups and lead to increased accumulation of aluminium in the body. A shortterm exceedance of a (P)TWI does not automatically result in a health risk. Nevertheless, considering regular longterm intake levels for aluminium of multiples of the $(\mathrm{P})$ TWI (Table 9), the existing contributions should be critically reviewed to reduce the overall aluminium exposure. This holds true even more if the severity of possible adverse effects (neurological damage, kidney and urinary tract damage) and the long half-life of aluminium in the human body are also taken into account. In this course, it seems suitable to
- exclusively breastfeed infants in the first 6 months, if possible

- examine the sources of contamination of foodstuffs with aluminium during production, processing and packaging (e.g. the elimination of aluminium baking trays in the production of lye biscuits (BfR 2002), the avoidance of uncoated aluminium meal trays to heat food or keep it warm (BfR 2017b)) and, where possible and appropriate, the use of raw materials with low aluminium content

- avoid contact of uncoated aluminium FCM with (especially) acidic and salty foodstuffs

- reduce usage of aluminium-containing cosmetics such as antiperspirants or abrasive toothpaste

\section{Compliance with ethical standards}

Conflict of interest The authors declare that they do not have potential conflicts of interest.

Open Access This article is distributed under the terms of the Creative Commons Attribution 4.0 International License (http://creativeco mmons.org/licenses/by/4.0/), which permits unrestricted use, distribution, and reproduction in any medium, provided you give appropriate credit to the original author(s) and the source, provide a link to the Creative Commons license, and indicate if changes were made.

\section{References}

AGES (2017) Aluminium in Lebensmitteln und anderen verbrauchernahen Produkten 2010-2017. Österreichische Agentur für Gesundheit und Ernährungssicherheit $\mathrm{GmbH}$, Wien, Österreich. https://www.ages.at/wissen-aktuell/publikationen/aluminium-inlebensmitteln-und-anderen-verbrauchernahen-produkten-20102017/. Accessed 24 Oct 2019

ANSES (2011) Second French total diet study (TDS 2)—report 1, inorganic contaminants, minerals, persistent organic pollutants, mycotoxins and phytoestrogens. French agency for food, environmental and occupational health and safety. https://www.anses .fr/en/system/files/PASER2006sa0361Ra1EN.pdf. Accessed 19 June 2019

ANSES (2016) Infant Total Diet Study (iTDS)-Tome 2-Partie 2, Composés inorganiques. French Agency for Food, Environmental and Occupational Health \& Safety. https://www.anses.fr/en/conte nt/infant-total-diet-study-itds. Accessed 19 June 2019

Arnich N, Sirot V, Rivière G et al (2012) Dietary exposure to trace elements and health risk assessment in the 2nd French Total Diet Study. Food Chem Toxicol 50(7):2432-2449. https://doi. org/10.1016/j.fct.2012.04.016

Beldì G, Jakubowska N, Peltzer MA, Simoneau C (2016) Testing approaches for the release of metals from ceramic articles - in support of the revision of the Ceramic Directive 84/500/EEC, EUR 28363 EN. https://doi.org/10.2788/402683

BfR (2002) Erhöhte Gehalte von Aluminium in Laugengebäck-Stellungnahme des BfR vom 25. November 2002. https://www.bfr. 
bund.de/cm/343/erhoehte_gehalte_von_aluminium_in_lauge ngebaeck.pdf. Accessed 19 June 2019

BfR (2007) Keine Alzheimer-Gefahr durch Aluminium aus Bedarfsgegenständen-Aktualisierte gesundheitliche Bewertung Nr. 033/2007 des BfR vom 22. Juli 2007. https://www.bfr.bund.de/ cm/343/keine_alzheimer_gefahr_durch_aluminium_aus_bedar fsgegenstaenden.pdf. Accessed 19 June 2019

BfR (2008) Aluminium in Apfelsaft: Lagerung von Fruchtsäften nicht in Aluminiumtanks-Gesundheitliche Bewertung Nr. 034/2008 des BfR vom 18. Juni 2008. https://www.bfr.bund.de/cm/343/ aluminium_in_apfelsaft_lagerung_von_fruchtsaeften_nicht _in_aluminiumtanks.pdf. Accessed 19 June 2019

BfR (2012) Aluminiumgehalte in Säuglingsanfangs- und Folgenahrung-Aktualisierte Stellungnahme Nr. 012/2012 des BfR vom 20. April 2012. https://www.bfr.bund.de/cm/343/aluminiumg ehalte-in-saeuglingsanfangs-und-folgenahrung.pdf. Accessed 19 June 2019

BfR (2014) Aluminiumhaltige Antitranspirantien tragen zur Aufnahme von Aluminium bei-Stellungnahme Nr. 007/2014 des BfR vom 26. Februar 2014. http://www.bfr.bund.de/cm/343/aluminiumh altige-antitranspirantien-tragen-zur-aufnahme-von-aluminiumbei.pdf. Accessed 19 June 2019

BfR (2017a) State of play on the subject of aluminium in cocoa and chocolate (unpublished data)

BfR (2017b) Unbeschichtete Aluminium-Menüschalen: Erste Forschungsergebnisse zeigen hohe Freisetzung von Aluminiumionen-Stellungnahme Nr. 007/2017 des BfR vom 29. Mai 2017. https://www.bfr.bund.de/cm/343/unbeschichtete-alumi nium-menueschalen-erste-forschungsergebnisse-zeigen-hohefreisetzung-von-aluminiumionen.pdf. Accessed 19 June 2019

Biego GH, Joyeux M, Hartemann P, Debry G (1998) Determination of mineral contents in different kinds of milk and estimation of dietary intake in infants. Food Addit Contam 15(7):775-781. https://doi.org/10.1080/02652039809374709

BVL (2019) BVL-Report 13.4 Berichte zur Lebensmittelsicherheit. Monitoring 2017. Bundesamt für Verbraucherschutz und Lebensmittelsicherheit. https://www.bvl.bund.de/SharedDocs/Downl oads/01_Lebensmittel/01_lm_mon_dokumente/01_Monitoring _Berichte/archiv/lmm_bericht_2017.pdf?__blob=publicatio nFile \&v=6. Accessed 19 June 2019

Candy JM, McArthur FK, Oakley AE et al (1992) Aluminium accumulation in relation to senile plaque and neurofibrillary tangle formation in the brains of patients with renal failure. J Neurol Sci 107(2):210-218. https://doi.org/10.1016/0022-510X(92)90291-R

CFS (2013) The First Hong Kong Total Diet Study Report No. 5. Centre for Food Safety, Food and Environmental Hygiene Department, The Government of the Hong Kong Special Administrative Region. https://www.cfs.gov.hk/english/programme/progr amme_firm/files/Report_on_1st_HKTDS_Metallic_Contaminan ts.pdf. Accessed 19 June 2019

Chao HH, Guo CH, Huang CB et al (2014) Arsenic, cadmium, lead, and aluminium concentrations in human milk at early stages of lactation. Pediatr Neonatol 55(2):127-134. https://doi. org/10.1016/j.pedneo.2013.08.005

Chuchu N, Patel B, Sebastian B, Exley C (2013) The aluminium content of infant formulas remains too high. BMC Pediatr 13:162. https://doi.org/10.1186/1471-2431-13-162

COT (2013) Statement on the potential risks from aluminium in the infant diet. Committee on toxicity of chemicals in food, consumer products and the environment (COT). https://cot.food. gov.uk/sites/default/files/cot/statealuminium.pdf. Accessed 19 June 2019

Dabeka R, Fouquet A, Belisle S, Turcotte S (2011) Lead, cadmium and aluminum in Canadian infant formulae, oral electrolytes and glucose solutions. Food Addit Contam Part A Chem Anal Control
Expo Risk Assess 28(6):744-753. https://doi.org/10.1080/19393 210.2011.571795

Darbre PD (2001) Underarm cosmetics are a cause of breast cancer. Eur J Cancer Prev 10(5):389-393

de Ligt R, van Duijn E, Grossouw D et al (2018) Assessment of dermal absorption of aluminum from a representative antiperspirant formulation using a $26 \mathrm{Al}$ microtracer approach. Clin Transl Sci. https://doi.org/10.1111/cts.12579

Dofkova M, Nurmi T, Berg K et al (2016) Development of harmonised food and sample lists for total diet studies in five European countries. Food Addit Contam A Chem Anal Control Expo Risk Assess 33(6):933-944. https://doi.org/10.1080/19440 049.2016 .1189770

EDQM (2013) Metals and alloys used in food contact materials and articles. Council of Europe, European Directorate for Quality of Medicines \& Healthcare, Strasbourg, France. https://www.edqm. eu/en/food-contact-materials. Accessed 24 Oct 2019

EFSA (2008) Safety of aluminium from dietary intake-scientific opinion of the panel on food additives, flavourings, processing aids and food contact materials (AFC). EFSA J 6(7):754. https://doi. org/10.2903/j.efsa.2008.754

EFSA (2011) The food classification and description system FoodEx 2 (draft-revision 1). EFSA Supporting Publications 8(12), 215E. https://doi.org/10.2903/sp.efsa.2011.EN-215

EFSA (2012) Guidance on selected default values to be used by the EFSA Scientific Committee, scientific panels and units in the absence of actual measured data. EFSA J 10(3):2579. https://doi. org/10.2903/j.efsa.2012.2579

EFSA (2018) Re-evaluation of aluminium sulphates (E 520-523) and sodium aluminium phosphate (E 541) as food additives. EFSA J 16(7):e05372. https://doi.org/10.2903/j.efsa.2018.5372

EFSA/FAO/WHO (2011) Towards a harmonised total diet study approach: a guidance document. In: EFSA Working Group on Total Diet Studies (ed). http://www.who.int/foodsafety/publicatio ns/tds_guidance/en/. Accessed 12 Sept 2019

Ertl K, Goessler W (2018) Aluminium in foodstuff and the influence of aluminium foil used for food preparation or short time storage. Food Addit Contam Part B 11(2):153-159. https://doi. org/10.1080/19393210.2018.1442881

Exley C, Charles LM, Barr L, Martin C, Polwart A, Darbre PD (2007) Aluminium in human breast tissue. J Inorg Biochem 101(9):1344-1346. https://doi.org/10.1016/j.jinor gbio.2007.06.005

Fakri S, Al-Azzawi A, Al-Tawil N (2006) Antiperspirant use as a risk factor for breast cancer in Iraq. East Mediterr Health $\mathrm{J}$ 12(3-4):478-482

Fernandez-Lorenzo JR, Cocho JA, Rey-Goldar ML, Couce M, Fraga JM (1999) Aluminum contents of human milk, cow's milk, and infant formulas. J Pediatr Gastroenterol Nutr 28(3):270-275

Filippini T, Tancredi S, Malagoli C et al (2019) Aluminum and tin: food contamination and dietary intake in an Italian population. J Trace Elem Med Biol 52:293-301. https://doi.org/10.1016/j. jtemb.2019.01.012

Finkelstein P, Wulf RJ (1974) The uptake, distribution, and excretion of a commercial aerosol antiperspirant by the monkey. J Soc Cosmet Chem 25(12):645-654

Fischer L (2014) Wie gefährlich ist Aluminium? In: Spektrum.de. https ://www.spektrum.de/wissen/wie-gefaehrlich-ist-aluminium-5fakten/1300812. Accessed 19 June 2019 (14.07.2014)

Flarend R, Bin T, Elmore D, Hem SL (2001) A preliminary study of the dermal absorption of aluminium from antiperspirants using aluminium-26. Food Chem Toxicol 39(2):163-168. https://doi. org/10.1016/S0278-6915(00)00118-6

FSANZ (2011) The 23rd Australian Total Diet Study. Food Standards Australia New Zealand. http://www.foodstandards.gov.au/publi 
cations/Pages/23rdaustraliantotald5367.aspx. Accessed 19 June 2019

FSANZ (2014) The 24th Australian Total Diet Study. Food Standards Australia New Zealand. http://www.foodstandards.gov.au/ publications/Documents/1778-FSANZ_AustDietStudy-web.pdf. Accessed 19 June 2019

Golub MS, Germann SL (2001) Long-term consequences of developmental exposure to aluminum in a suboptimal diet for growth and behavior of Swiss Webster mice. Neurotoxicol Teratol 23(4):365-372. https://doi.org/10.1016/S0892-0362(01)00144-1

Hunnius C (2014) Pharmazeutisches Wörterbuch, 11. Auflage vom 15. August 2014, 11th edn. De Gruyter, Berlin

IAI (2018) Primary aluminium production in 2018, world aluminium - the website of the International Aluminium Institute. In: http://www.world-aluminium.org/statistics/\#map. Accessed 19 June 2019

IKW (2016a) Group data sheet No 73: Antiperspirant aerosol spray (with antiperspirant salt). In: http://gmb.ikw.org/index _en.php? $\mathrm{p}=\mathrm{mb} \& \mathrm{id}=159 \&$ action $=$ selectMerkblatt. Accessed 19 June 2019

IKW (2016b) Group data sheet No 79: Antiperspirant creme. In: http://gmb.ikw.org/index_en.php? $\mathrm{p}=\mathrm{mb} \& \mathrm{id}=159 \&$ actio $\mathrm{n}=$ selectMerkblatt. Accessed 19 June 2019

IKW (2016c) Group data sheet No 128: Antiperspirant liquid squeeze pack or pump spray (with antiperspirant salt). In: http://gmb. ikw.org/index_en.php? $=$ mb\&id $=159 \&$ action $=$ selectMerk blatt. Accessed 19 June 2019

IKW (2016d) Group data sheet No 129: Antiperspirant rollon (with antiperspirant salt). In: http://gmb.ikw.org/index _en.php? $\mathrm{p}=\mathrm{mb} \& \mathrm{id}=159 \&$ action $=$ selectMerkblatt. Accessed 19 June 2019

Inan-Eroglu E, Ayaz A (2018) Is aluminum exposure a risk factor for neurological disorders? J Res Med Sci 23:51. https://doi. org/10.4103/jrms.JRMS_921_17

Inker LA, Levey AS (2014) 3-assessment of glomerular filtration rate in acute and chronic settings. In: Gilbert SJ, Weiner DE (eds) National Kidney Foundation Primer on Kidney Diseases, 6th edn. W.B. Saunders, Philadelphia, pp 26-32

Ionescu JG, Novotny J, Stejskal V, Lätsch A, Blaurock-Busch E, Eisenmann-Klein M (2007) Breast tumours strongly accumulate transition metals. Maedica J Clin Med 2(1):5-11

IPCS (1997) Environmental Health Criteria 194-Aluminium. International Programme on Chemical Safety. http://www.inche m.org/documents/ehc/ehc/ehc194.htm. Accessed 19 June 2019

JECFA (2007) Safety evaluation of certain food additives and contaminants Prepared by the Sixty-seventh meeting of the Joint FAO/WHO Expert Committee on Food Additives (JECFA), $\mathrm{CH}$, series 58. World Health Organization, Geneva

JECFA (2012) Safety evaluation of certain food additives and contaminants prepared by the Seventy-fourth meeting of the Joint FAO/WHO Expert Committee on Food Additives, $\mathrm{CH}$, series 65. World Health Organization, Geneva

Klein GL (2019) Aluminum toxicity to bone: a multisystem effect? Osteoporos Sarcopenia 5(1):2-5. https://doi.org/10.1016/j. afos.2019.01.001

Klotz K, Meyer-Baron M, van Thriel C et al (2018) Addendum zu Aluminium [BAT Value Documentation in German language, 2018]. MAK Collect Occup Health Saf. https://doi. org/10.1002/3527600418.bb742990verd0023

Klotz K, Drexler H, Hartwig A, Commission MAK (2019) Addendum zu Aluminium [BAT Value Documentation in German language, 2019]. MAK Collect Occup Health Saf. https://doi. org/10.1002/3527600418.bb742990verd0024

Kolbaum AE, Berg K, Müller F, Kappenstein O, Lindtner O (2019) Dietary exposure to elements from the German Pilot Total
Diet Study (TDS). Food Addit Contam Part A. https://doi. org/10.1080/19440049.2019.1668967

Krachler M, Prohaska T, Koellensperger G, Rossipal E, Stingeder G (2000) Concentrations of selected trace elements in human milk and in infant formulas determined by magnetic sector field inductively coupled plasma-mass spectrometry. Biol Trace Elem Res 76(2):97-112. https://doi.org/10.1385/bter:76:2:97

Krems C, Bauch A, Götz A et al (2006) Methoden der Nationalen Verzehrsstudie II. Ernähr Umschau 53(2):44-50

Krewski D, Yokel RA, Nieboer E et al (2007) Human health risk assessment for aluminium, aluminium oxide, and aluminium hydroxide. J Toxicol Environ Health Part B 10(sup1):1-269. https://doi.org/10.1080/10937400701597766

LAVES (2017) Tätigkeitsbericht 2016. Niedersächsisches Landesamt für Verbraucherschutz und Lebensmittelsicherheit (LAVES), Oldenburg, Germany, p 93. https://www.laves.niedersachsen.de/ service/publikationen/jahresberichte_verbraucherschutzberichte /taetigkeitsbericht-2016-156888.html. Accessed 24 Oct 2019

Lenhart CM, Wiemken A, Hanlon A, Perkett M, Patterson F (2017) Perceived neighborhood safety related to physical activity but not recreational screen-based sedentary behavior in adolescents. BMC Public Health. https://doi.org/10.1186/s12889-017-4756-z

LGL (2018) LGL Jahresbericht 2017. Bayerisches Landesamt für Gesundheit und Lebensmittelsicherheit. https://www.lgl.bayer n.de/publikationen/doc/lgl_jahresbericht_2017.pdf. Accessed 19 June 2019

Liang J, Liang X, Cao P et al (2019) A preliminary investigation of naturally occurring aluminum in grains, vegetables, and fruits from some areas of China and dietary intake assessment. J Food Sci 84(3):701-710. https://doi.org/10.1111/1750-3841.14459

Liu S, Hammond SK, Rojas-Cheatham A (2013) Concentrations and potential health risks of metals in lip products. Environ Health Perspect 121:705-710. https://doi.org/10.1289/ehp.1205518

Lubecki M (2014) Daily dose of aluminium —a health risk? Absorption via food, cosmetics and other consumer products. In: Chemisches und Veterinäruntersuchungsamt Stuttgart/Baden-Württemberg. http://www.cvuas.de/pub/beitrag.asp?subid=1\&Thema_ID $=3 \&$ $\mathrm{ID}=2012 \&$ lang $=\mathrm{EN} \& \mathrm{Pdf}=$ No. Accessed 19 June 2019

Lukiw WJ, Kruck TPA, Percy ME et al (2019) Aluminum in neurological disease-a 36 year multicenter study. J Alzheimers Dis Parkinsonism 8(6):457. https://doi.org/10.4172/2161-0460.1000457

Mannello F, Tonti GA, Medda V, Simone P, Darbre PD (2011) Analysis of aluminium content and iron homeostasis in nipple aspirate fluids from healthy women and breast cancer-affected patients. J Appl Toxicol 31(3):262-269. https://doi.org/10.1002/jat.1641

Manová E, von Goetz N, Keller C, Siegrist M, Hungerbühler K (2013) Use patterns of leave-on personal care products among SwissGerman children, adolescents, and adults. Int J Environ Res Public Health 10(7):2778-2798. https://doi.org/10.3390/ijerp h10072778

Martinez CS, Vera G, Ocio JAU et al (2018) Aluminum exposure for 60 days at an equivalent human dietary level promotes peripheral dysfunction in rats. J Inorg Biochem 181:169-176. https://doi. org/10.1016/j.jinorgbio.2017.08.011

Mehpara Farhat S, Mahboob A, Ahmed T (2019) Oral exposure to aluminum leads to reduced nicotinic acetylcholine receptor gene expression, severe neurodegeneration and impaired hippocampus dependent learning in mice. Drug Chem Toxicol. https://doi. org/10.1080/01480545.2019.1587452

Mirick DK, Davis S, Thomas DB (2002) Antiperspirant use and the risk of breast cancer. JNCI J Natl Cancer Inst 94(20):1578-1580. https://doi.org/10.1093/jnci/94.20.1578

Mold M, Cottle J, King A, Exley C (2019) Intracellular aluminium in inflammatory and glial cells in cerebral amyloid angiopathy: a case report. Int J Environ Res Public Health. https://doi. org/10.3390/ijerph16081459 
MPI (2016) 2016 New Zealand Total Diet Study. Ministry for Primary Industries of New Zealand. https://www.mpi.govt.nz/food-safet y/food-monitoring-and-surveillance/new-zealand-total-diet-study /. Accessed 12 Sept 2019

MRI (2008) Nationale Verzehrsstudie II—Die bundesweite Befragung zur Ernährung von Jugendlichen und Erwachsenen. Ergebnisbericht, Teil 2. Max Rubner-Institut-Bundesforschungsinstitut für Ernährung und Lebensmittel, Karlsruhe DE. https://www.bmel. de/SharedDocs/Downloads/Ernaehrung/NVS_Ergebnisbericht Teil2.pdf. Accessed 12 Sept 2019

Namer M, Luporsi E, Gligorov J, Lokiec F, Spielmann M (2008) The use of deodorants/antiperspirants does not constitute a risk factor for breast cancer. Bull Cancer 95(9):871-880. https://doi. org/10.1684/bdc.2008.0679

Nicholson S, Exley C (2007) Aluminum: a potential pro-oxidant in sunscreens/sunblocks? Free Radic Biol Med 43(8):1216-1217. https://doi.org/10.1016/j.freeradbiomed.2007.07.010

Nie J (2018) Exposure to aluminum in daily life and Alzheimer's disease. In: Niu Q (ed) Neurotoxicity of aluminum advances in experimental medicine and biology, vol 1091. Springer, Singapore. https://doi.org/10.1007/978-981-13-1370-7_6

NILU (2011) Metaller i næringsmidler, kroppspleieprodukter og kosmetikk. Bestemmelse av aluminium, kadmium og barium. Oppdragsrapport. (NILU OR 16/2011). Norwegian Institute for Air Research. ISBN: 978-82-425-2377-8

Ogoshi K, Yanagi S, Moriyama T, Arachi H (1994) Accumulation of aluminum in cancers of the liver, stomach, duodenum and mammary glands of rats. J Trace Elem Electrolytes Health Dis $8(1): 27-31$

Oneda S, Takasaki T, Kuriwaki K et al (1994) Chronic toxicity and tumorigenicity study of aluminum potassium sulfate in $\mathrm{B} 6 \mathrm{C} 3 \mathrm{~F} 1$ mice. In Vivo 8(3):271-278

PEI (2015) Sicherheitsbewertung von Aluminium in Impfstoffen. Bulletin zur Arzneimittelsicherheit Informationen aus BfArM und PEI (3):7. https://www.pei.de/SharedDocs/Downloads/vigil anz/bulletin-zur-arzneimittelsicherheit/2015/3-2015.pdf? blob $=$ publicationFile $\& v=10$. Accessed 19 June 2019

Pi X, Jin L, Li Z et al (2019) Association between concentrations of barium and aluminum in placental tissues and risk for orofacial clefts. Sci Total Environ 652:406-412. https://doi.org/10.1016/j. scitotenv.2018.10.262

Pineau A, Guillard O, Fauconneau B et al (2012) In vitro study of percutaneous absorption of aluminum from antiperspirants through human skin in the Franz ${ }^{\mathrm{TM}}$ diffusion cell. J Inorg Biochem 110:21-26. https://doi.org/10.1016/j.jinorgbio.2012.02.013

Poirier J, Semple H, Davies J et al (2011) Double-blind, vehiclecontrolled randomized twelve-month neurodevelopmental toxicity study of common aluminum salts in the rat. Neuroscience 193:338-362. https://doi.org/10.1016/j.neuroscien ce.2011.05.008

Priest N, Newton D, Day J, Talbot R, Warner A (1995) Human metabolism of aluminium-26 and gallium-67 injected as citrates. Hum Exp Toxicol 14(3):287-293. https://doi.org/10.1177/0960327195 01400309

RIVM (2006) Cosmetics Fact Sheet to assess the risks for the consumer, Updated version for ConsExpo 4, RIVM report 320104001/2006. Rijksinstituut voor Volksgezondheid en Milieu. https://www.rivm.nl/bibliotheek/rapporten/320104001. pdf. Accessed 24 Oct 2019

RKI (2016) The 20 most frequent objections to vaccinations-and responses by immunisation experts of the Robert Koch Institute and the Paul-Ehrlich-Institut. In: https://www.rki.de/EN/Conte nt/Institute/DepartmentsUnits/InfDiseaseEpidem/Div33/Objec tions_and_Responses.html. Accessed 19 June 2019

RKI (2017) Vaccination schedule In: Robert Koch-Institut. https:// www.rki.de/DE/Content/Infekt/Impfen/Materialien/Downl
oads-Impfkalender/Impfkalender_Englisch.pdf?_blob=publi cationFile. Accessed 19 June 2019

Rodriguez J, Mandalunis PM (2018) A review of metal exposure and its effects on bone health. J Toxicol 2018:4854152. https://doi. org/10.1155/2018/4854152

Romaniuk A, Lyndin M, Sikora V, Lyndina Y, Romaniuk S, Sikora K (2017) Heavy metals effect on breast cancer progression. J Occup Med Toxicol (London, England) 12:32. https://doi.org/10.1186/ s12995-017-0178-1

Romanowicz-Makowska H, Forma E, Bryś M, Krajewska WM, Smolarz B (2012) Concentration of cadmium, nickel and aluminium in female breast cancer. Pol J Pathol 62(4):257-261

RoteListe (2018) Rote Liste-Arzneimittelinformationen für Deutschland In. https://online.rote-liste.de/. Accessed 19 June 2019

Sander S, Kappenstein O, Ebner I et al (2018) Release of aluminium and thallium ions from uncoated food contact materials made of aluminium alloys into food and food simulant. PLoS One 13(7):e0200778. https://doi.org/10.1371/journal.pone.0200778

SCCS (2014) Opinion on the safety of aluminium in cosmetic products. SCCS/1525/14. Scientific Committee on Consumer Safety. http://ec.europa.eu/health/sites/health/files/scientific_committees /consumer_safety/docs/sccs_o_153.pdf. Accessed 12 Sept 2019

SCCS (2018) The notes of guidance for the testing of cosmetic ingredients and their safety evaluation 10th. revision. SCCS/1602/18. Scientific Committee on Consumer Safety. https://ec.europa.eu/ health/sites/health/files/scientific_committees/consumer_safety/ docs/sccs_o_224.pdf. Accessed 12 Sept 2019

SCHEER (2017) Final opinion on tolerable intake of aluminium with regards to adapting the migration limits for aluminium in toys. Scientific Committee on Health, Environmental and Emerging Risks. https://doi.org/10.2875/264211

Seidowsky A, Dupuis E, Drueke T, Dard S, Massy ZA, Canaud B (2018) Intoxication aluminique en hémodialyse chronique. Un diagnostic rarement évoqué de nos jours. Illustration par un cas clinique et revue de la littérature. Néphrologie Thérapeutique 14(1):35-41. https://doi.org/10.1016/j.nephro.2017.04.002

Sirot V, Traore T, Guérin T et al (2018) French infant total diet study: exposure to selected trace elements and associated health risks. Food Chem Toxicol 120:625-633. https://doi.org/10.1016/j. fct.2018.07.062

VKM (2013) Risk assessment of the exposure to aluminium through food and the use of cosmetic products in the Norwegian population. (VKM Report 2013: 20). Norwegian Scientific Committee for Food Safety. https://vkm.no/download/18.175083d415c86c5 73b59c179/1501678206406/a729a67e65.pdf. Accessed 12 Sept 2019

WHO (2007) Model list of essential medicines-15th list (March 2007). World Health Organization, Geneva

WHO (2012) Global Advisory Committee on Vaccine Safety, report of meeting held 6-7 June 2012. In: World Health Organization. http://www.who.int/vaccine_safety/committee/reports/Jun_2012/ en/. Accessed 19 June 2019

WHO (2017) Model List of Essential Medicines-20th list (March 2017) (Amended August 2017). World Health Organization, Geneva

Yokel RA, McNamara PJ (2001) Aluminium toxicokinetics: an updated minireview. Pharmacol Toxicol 88(4):159-167. https://doi.org/1 $0.1111 / \mathrm{j} .1600-0773.2001 .880401 . x$

Publisher's Note Springer Nature remains neutral with regard to jurisdictional claims in published maps and institutional affiliations. 